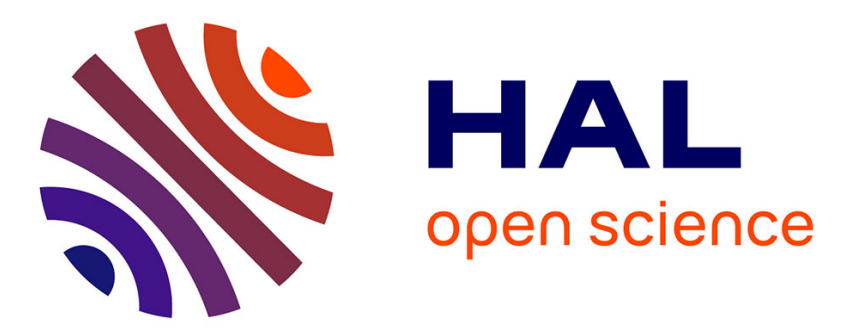

\title{
Signal transduction protein PII from Synechococcus elongatus PCC 7942 senses low adenylate energy charge in vitro.
}

\author{
Oleksandra Fokina, Christina Herrmann, Karl Forchhammer
}

\section{- To cite this version:}

Oleksandra Fokina, Christina Herrmann, Karl Forchhammer. Signal transduction protein PII from Synechococcus elongatus PCC 7942 senses low adenylate energy charge in vitro.. Biochemical Journal, 2011, 440 (1), pp.147-156. 10.1042/BJ20110536 . hal-00642840

\section{HAL Id: hal-00642840 \\ https://hal.science/hal-00642840}

Submitted on 19 Nov 2011

HAL is a multi-disciplinary open access archive for the deposit and dissemination of scientific research documents, whether they are published or not. The documents may come from teaching and research institutions in France or abroad, or from public or private research centers.
L'archive ouverte pluridisciplinaire HAL, est destinée au dépôt et à la diffusion de documents scientifiques de niveau recherche, publiés ou non, émanant des établissements d'enseignement et de recherche français ou étrangers, des laboratoires publics ou privés. 


\section{Signal transduction protein $P_{\text {II }}$ from Synechococcus elongatus PCC 7942 senses low adenylate energy charge in vitro.}

Short title: Adenylate energy charge sensing by cyanobacterial $\mathrm{P}_{\mathrm{II}}$ protein

\section{Oleksandra Fokina, Christina Herrmann and Karl Forchhammer ${ }^{1}$}

Interfakultäres Institut für Mikrobiologie und Infektionsmedizin der Eberhard-Karls-Universität Tübingen, Auf der Morgenstelle 28, 72076 Tübingen, Germany

\section{Synopsis}

$\mathrm{P}_{\text {II }}$ proteins belong to a family of highly conserved signal transduction proteins widely spread in bacteria, archaea and plants. They respond to the central metabolites ATP, ADP and 2-oxoglutarate (2-OG) and control enzymes, transcription factors and transport proteins involved in nitrogen metabolism. Here we studied the effect of ADP on in vitro $\mathrm{P}_{\mathrm{II}}$ signalling properties from the cyanobacterium Synechococcus elongatus, a model for oxygenic phototrophic organisms. Different ADP/ATP ratios strongly affected the properties of $\mathrm{P}_{\mathrm{II}}$ signalling. Increasing ADP antagonized the binding of 2-oxoglutarate and directly affected the interactions of $\mathrm{P}_{\mathrm{II}}$ with its target proteins. The resulting $\mathrm{P}_{\mathrm{II}}$ signalling properties indicate that in mixtures of $\mathrm{ADP}$ and $\mathrm{ATP}, \mathrm{P}_{\mathrm{II}}$ trimers are occupied with mixtures of adenylate nucleotides. Binding and kinetic activation of $N$-acetyl-Lglutamate kinase (NAGK) (the controlling enzyme of arginine biosynthesis) by $\mathrm{P}_{\mathrm{II}}$ was weakened by ADP, but relief from arginine inhibition remained unaffected. On the other hand, ADP enhanced the binding of $\mathrm{P}_{\mathrm{II}}$ to PipX, a co-activator of transcription factor NtcA and furthermore, antagonised the inhibitory effect of $2-\mathrm{OG}$ on $\mathrm{P}_{\mathrm{II}} \mathrm{PipX}$ interaction. These results indicate that $S$. elongatus $\mathrm{P}_{\mathrm{II}}$ directly senses the adenylate energy charge, resulting in target-dependent differential modification of the $\mathrm{P}_{\mathrm{II}}$ signalling properties.

Key words: metabolic signalling, nitrogen regulation, 2-oxoglutarate, $\mathrm{P}_{\mathrm{II}}$ protein, energy charge, cyanobacteria

Abbreviations used: EC, energy charge; 2-OG, 2-oxoglutarate; NAGK, $N$-acetyl-L-glutamate kinase; SPR, surface plasmon resonance; ITC, isothermal titration calorimetry; FC, flow cell; RU, resonance units; NAG, $\mathrm{N}$-acetyl-L-glutamate

${ }^{1}$ To whom correspondence should be addressed (email karl.forchhammer@uni-tuebingen.de) 


\section{Introduction}

ATP in the cell provides energy for metabolic reactions, serves as a substrate for nucleotide synthesis and regulates cell metabolism as a signal molecule. The adenylate energy charge (EC), $[($ adenosine triphosphate $)+$ (adenosine diphosphate) $] /[$ (adenosine triphosphate) + (adenosine diphosphate $)+($ adenosine monophosphate $)$ is a measure of the energy available for metabolism [1]. Since in bacteria the concentration of AMP is constantly low, the adenylate energy charge depends mainly on the ATP/ADP ratio [2]. However, sensors of the adenylate energy charge have been poorly characterized. Recently the $\mathrm{P}_{\mathrm{II}}$ signal transduction proteins have been suggested to be involved in EC measurement. They respond to ATP, ADP and 2-oxoglutarate (2-OG) by binding these effectors in an interdependent manner [3-7], thereby transmitting metabolic information into structural states of the $\mathrm{P}_{\mathrm{II}}$ sensor protein $[8,9]$. $\mathrm{P}_{\mathrm{II}}$ when fully occupied by either ATP or ADP corresponds to non-physiological extremes of EC. To understand how $P_{I I}$ responds to physiologically relevant changes in EC, experiments must be conducted with different ATP/ADP ratios that span physiological conditions.

$\mathrm{P}_{\mathrm{II}}$ signal transduction proteins are widely distributed in bacteria, archaea and the chloroplasts of eukaryotes, where they regulate metabolic and regulatory enzymes, transcription factors and/or transport proteins [4, 10-12]. In addition to responding to the metabolites ATP, ADP and 2oxoglutarate (2-OG), $\mathrm{P}_{\text {II }}$ proteins can furthermore be subjected to signal-dependent reversible covalent modification, which occurs on the large surface exposed $\mathrm{T}$-loop $[10,13]$. $\mathrm{P}_{\text {II }}$ proteins are compact homotrimers with each subunit exposing three surface-exposed loops, termed T-loop, Bloop and C-loop [4]. The large T-loop is highly flexible and adopts different conformations, taking part in binding of effector molecules and being the dominating structure in protein-protein interactions. The B- and C-loops from opposite subunits are facing each other in the intersubunit cleft and take part in adenylate nucleotide binding [14-16]. The $\mathrm{P}_{\mathrm{II}}$ trimer contains three adenylate nucleotide-binding sites, one in each intersubunit cleft, with ATP and ADP competing for the same site. In the presence of $\mathrm{Mg}^{2+}-\mathrm{ATP}$, up to three $2-\mathrm{OG}$ molecules can bind to the protein at the base of the T-loop in direct vicinity of the beta and gamma-phosphate of ATP, which ligate 2-OG through a bridging $\mathrm{Mg}^{2+}$ ion [8-10]. Through this type of interaction, binding of ATP and 2-OG at one effector molecule binding site is synergistic towards each other. However, the three effector molecule binding sites exhibit negative cooperativity towards each other [3, 6, 17, 18]. The anticooperativity is mediated via intersubunit signalling [19]. First structural insight in this process was obtained recently for sequential 2-OG binding [8]. Occupation of the first, high affinity site, creates structural differences in the two neighboring sites, with one site displaying a clear distortion in the conformation of the bound ATP molecule. The anticooperativity in the binding of the effector results in a subsensitive response of this stimulatory effect, which is ideal for accurate detection of a wide range of metabolite concentrations.

Adenyl nucleotide binding seems to be highly similar in all $\mathrm{P}_{\text {II }}$ proteins from the three domains of life. In bacterial $\mathrm{P}_{\mathrm{II}}$ proteins, $\mathrm{ADP}$ generally does not support 2-OG binding $[3,7]$, whereas in a plant $\mathrm{P}_{\mathrm{II}}$ protein (Arabidopsis thaliana) 2-OG binding was supported both by ATP and ADP [20]. Effects of different ADP/ATP ratios have so for only been studied in vitro with $E$. coli $\mathrm{P}_{\mathrm{II}}$ protein $[3,18]$. Increasing ADP levels act antagonistically to $2-\mathrm{OG}$ in the UTase/UR-P $\mathrm{II}_{\mathrm{I}} \mathrm{NRII-NRI}$ signal transduction cascade in vitro. Furthermore, ADP acts through $\mathrm{P}_{\mathrm{II}}$ as an activator of ATase catalyzed glutamine synthetase adenylylation in the ATase-GS monocycle. On the other hand, the uridylylation of $\mathrm{P}_{\mathrm{II}}$ by UTase is negatively influenced by ADP [3]. ADP increases the stability of the complex of the $\mathrm{P}_{\mathrm{II}}$-family protein GlnK with the ammonium channel AmtB and antagonizes the effect of 2-OG, pointing at the $\mathrm{P}_{\mathrm{II}}$ sensing of the adenylate energy charge [7]. In the photosynthetic bacterium Rhodospirillum rubrum, three $\mathrm{P}_{\mathrm{II}}$ homologues are involved in the regulation of the transcription activator NifA and the DRAT/DRAG system for the posttranslational regulation of nitrogenase activity [21-23]. The DRAT/DRAG system responds to the energy state, pointing towards a connection of $\mathrm{P}_{\mathrm{II}}$ with the energy status in the cell [22]. However, there is only slight 
impact of low ATP levels alone on the $\mathrm{P}_{\text {II }}$ regulation of both processes, supposedly, the ratio of $\mathrm{ADP} / \mathrm{ATP}$ is significant this response [5].

In cyanobacteria $\mathrm{P}_{\mathrm{II}}$ is involved in nitrate utilization $[24,25]$, regulation of gene expression by sequestering the co-activator PipX of the general transcription factor NtcA [26-28], and in arginine biosynthesis by regulating the controlling enzyme, $N$-acetyl-L-glutamate kinase (NAGK) [29, 30]. Binding of $\mathrm{P}_{\mathrm{II}}$ from the cyanobacterium Synechococcus elongatus enhances the activity of NAGK and relieves it from feedback inhibition by arginine [31]. In higher plants, $\mathrm{P}_{\mathrm{II}}$ also regulates NAGK [32] and, moreover, A thaliana $\mathrm{P}_{\mathrm{II}}$ binds and inhibits a key enzyme of fatty acid metabolism, acetyl-CoA carboxylase [33], representing another link between $\mathrm{P}_{\mathrm{II}}$ and carbon metabolism. The structure of the $\mathrm{P}_{\mathrm{II}}-\mathrm{NAGK}$ complex, NAGK regulation by $\mathrm{P}_{\mathrm{II}}$ and its response towards 2-OG are highly conserved between higher plants and cyanobacteria [34-36]. In the presence of $\mathrm{Mg}^{2+}-\mathrm{ATP}$, 2-OG strongly inhibits $\mathrm{P}_{\mathrm{II}}$-NAGK complex formation. Whereas in cyanobacteria, $\mathrm{Mg}^{2+}$-ATP alone has only a slight effect on complex formation [6,31], it favours the binding of $\mathrm{P}_{\mathrm{II}}$ to NAGK in $A$. thaliana [20]. ADP accelerates the dissociation of the cyanobacterial proteins but has no major effect on the $A$. thaliana proteins [36].

The $S$. elongatus $\mathrm{P}_{\text {II }}$ protein is subjected to phosphorylation and dephosphorylation in response to the cellular 2-OG and ATP levels [37]. In vitro, high concentrations of 2-OG in presence of ATP cause phosphorylation of seryl-residue 49, an exposed residue at the apex of the T-loop [38]. The $\mathrm{P}_{\mathrm{II}}$ kinase has not been identified yet. The phosphatase of $\mathrm{P}_{\mathrm{II}} \mathrm{P}$, PphA from Synechocystis PCC 6803, readily dephosphorylates $\mathrm{P}_{\mathrm{II}} \mathrm{P}$ in the absence of effector molecules. This reaction is partially inhibited by ATP or ADP, but strongly by $\mathrm{Mg}^{2+}-\mathrm{ATP}-2-\mathrm{OG}$ [39]. Combining different mixtures of $\mathrm{ADP} / \mathrm{ATP}$ and 2-OG revealed that the $\mathrm{P}_{\mathrm{II}}$ dephosphorylation reaction responded highly sensitive towards the 2-OG levels, however changing the ATP/ADP ratio had only little effect [40], since both adenylate nucleotides inhibit the dephosphorylation reaction. In contrast, preliminary data indicate that ATP and ADP antagonistically influence the binding of $\mathrm{P}_{\mathrm{II}}$ with its targets NAGK or PipX. This could indicate that the interaction of $P_{I I}$ with its downstream signalling targets is indeed responsive to the ATP/ADP level, as was reported for the interaction of the $\mathrm{P}_{\text {II }}$ protein from E. coli with its targets NtrB and ATase [3].

In this study we investigate the ability of $S$. elongatus $\mathrm{P}_{\text {II }}$ to act as an EC sensor in vitro, and found that indeed it has such ability. Interestingly, the two targets, NAGK and PipX, respond differently to changing ADP/ATP ratios, with PipX being more sensitive towards low ADP levels. Furthermore, we observed that the effects of EC were mediated both indirectly, by changing the 2OG binding properties of $\mathrm{P}_{\mathrm{II}}$, and directly, by the alteration of $\mathrm{P}_{\mathrm{II}}$ output activities upon the binding of mixtures of nucleotides to $\mathrm{P}_{\mathrm{II}}$.

\section{Experimental}

\section{Construction of heterotrimeric $P_{\text {II }}$ protein}

Heterotrimeric $\mathrm{P}_{\mathrm{II}}$-proteins, consisting of the Strep-tagged and non-tagged subunits were constructed as follows: two glnB genes from Synechococcus elongatus, one carrying Strep-tag fusion, another without Strep-tag, were cloned into pETDuet-1 vector (Merck KGaA, Darmstadt, Germany). First, native $g \ln B$ was amplified using primers containing AatII and AvrII restriction sites: $\quad \mathrm{P}_{\mathrm{II}} \mathrm{nfwd} 2$ (5'-ATGCGACGTCGATAACGAGGGCAAAA-3') and P ${ }^{\prime}$ IInrev2 (5' ATGCCCTAGGGTAAACGGCAGACAAA-3'). The PCR product was restricted with AatII and AvrII and cloned into multiple cloning site 2 (MCS2) of pETDuet-1 vector. The resulting plasmid was restricted with $\mathrm{NcoI}$ and HindIII for the insertion of Strep-tag-fused $g \ln B$ into multiple cloning site 1 (MCS1). The amplification of the second gene was done using following primers: $\mathrm{P}_{\mathrm{II}} \mathrm{sfor}\left(5^{\prime}-\right.$ ATGCCCATGGTTACCACTCCCTATCAGT-3') and P IIsrev (5'ATGCAAGCTTCGCAGTAGCGGTAAAC-3'). The clones were checked by sequencing with the primers pET-Upstream (5'-ATGCGTCCGGCGTAGA-3') for MCS1 and T7-Terminator (5'GCTAGTTATTGCTCAGCGG-3') for MCS2. 


\section{Overexpression and purification of recombinant $P_{\text {II }}$, NAGK, PipX and AGPR}

The glnB gene from Synechococcus elongatus, cloned into the Strep-tag fusion vector pASK-IBA3 (IBA, Göttingen, Germany), was overexpressed in E. coli RB9060 [41] and purified using affinity chromatography as described previously [30]. The His -tagged recombinant NAGK from $S$. elongatus, His ${ }_{6}$-tagged PipX and N-acetylglutamate-5-phosphate-reductase (AGPR) from E. coli were overexpressed in E. coli strain BL21(DE3) [42] and purified as reported previously [26, 30, 43]. Heterotrimeric $\mathrm{P}_{\mathrm{II}}$ was overexpressed in E. coli strain BL21(DE3) and purified as described above with following modification: protein elution was made with a gradient of $30 \mu \mathrm{M}, 200 \mu \mathrm{M}$ and $1 \mathrm{mM}$ desthiobiotin, and analysed by SDS-PAGE. $\mathrm{P}_{\mathrm{II}}$ trimers with one/two Strep-tags were localized in $200 \mu \mathrm{M}$ desthiobiotin fractions.

\section{Surface Plasmon Resonance Detection (SPR)}

SPR experiments were performed using a BIAcore $\mathrm{X}$ biosensor system (Biacore $\mathrm{AB}$, Uppsala, Sweden) at $25^{\circ} \mathrm{C}$ in HBS-Mg buffer containing $10 \mathrm{mM}$ HEPES, $150 \mathrm{mM} \mathrm{NaCl}, 1 \mathrm{mM} \mathrm{MgCl} \mathrm{m}_{2}$ and $0.005 \%$ Nonidet P-40, pH 7.5 as described previously [31]. The purified His 6 -NAGK was immobilized on the $\mathrm{Ni}^{+}$-loaded NTA sensor chip to flow cell 2 (FC2) in a volume of $50 \mu \mathrm{l}$ at a concentration of $30 \mathrm{nM}$ (hexamer) to receive a binding signal of approximately 3000 resonance units (RU), which corresponds to a surface concentration change of $3 \mathrm{ng} / \mathrm{mm}^{2}$. To determine the influence of different ATP/ADP ratios on the association and dissociation of the $\mathrm{P}_{\mathrm{II}} \mathrm{NAGK}$ complex, a solution of $100 \mathrm{nM} \mathrm{P}_{\mathrm{II}}$ was injected over the sensor-chip immobilized His ${ }_{6}$-NAGK surface in the presence of $2 \mathrm{mM}$ ATP with $0,1,2,3$, or $4 \mathrm{mM}$ ADP as well as in the presence of 2 mM ADP alone. $\mathrm{P}_{\mathrm{II}}$ was afterwards eluted by an injection of the same proportion of the metabolites. Furthermore, $100 \mathrm{nM} \mathrm{P}_{\text {II }}$ was bound over the immobilized NAGK with or without $1 \mathrm{mM}$ ADP and eluted by an injection of $1 \mathrm{mM}$ ADP. To load fresh proteins on the NTA sensor chip, bound proteins were first removed by injection of $25 \mu \mathrm{l}$ of $0.4 \mathrm{M}$ EDTA pH 7.5, subsequently, the chip could be loaded again with $5 \mathrm{mM} \mathrm{Ni}_{2} \mathrm{SO}_{4}$ solution and $\mathrm{His}_{6}$-NAGK as described above.

$\mathrm{P}_{\mathrm{II}}$-PipX complex formation on the NTA chip was measured as described previously [26]. The His $6^{-}$ PipX (500 nM) was preincubated with homotrimeric Strep- $\mathrm{P}_{\mathrm{II}}(100 \mathrm{nM}$ monomer $)$ in the absence and in the presence of effectors and injected on the $\mathrm{Ni}^{2+}$-loaded NTA chip. As a control, His 6 -PipX was bound to the chip in the absence of $\mathrm{P}_{\mathrm{II}}$. The response difference between binding of His 6 -PipX alone and in the presence of $\mathrm{P}_{\mathrm{II}}$ at $\mathrm{t}=197 \mathrm{~s}$ after start of the injection phase, was taken as a measure of protein binding.

To assay the binding of PipX to immobilized $\mathrm{P}_{\mathrm{II}}$, a CM5 sensor chip was treated with Amino Coupling Kit (Biacore AB, Uppsala, Sweden) to bind Strep-Tactin protein $(50 \mu \mathrm{g} / \mu \mathrm{l})$ in a volume $50 \mu \mathrm{l}$ on the surface [28]. Thereafter, the purified heterotrimeric or homotrimeric-Strep-tagged $\mathrm{P}_{\mathrm{II}}$ $(40 \mathrm{ng} / \mu \mathrm{l})$ was immobilized on the chip surface in flow cell 2 (FC2) in a volume of $20 \mu \mathrm{l}$. PipX (21 $\mathrm{ng} / \mu \mathrm{l}$ ) was injected in a volume of $20 \mu \mathrm{l}$ in the presence of following effectors: $2 \mathrm{mM} \mathrm{ADP}, 2 \mathrm{mM}$ ATP and $1 \mathrm{mM}$ 2-OG. To remove $\mathrm{P}_{\mathrm{II}}$ from the surface, the chip was washed with $5 \mathrm{mM}$ desthiobiotin and regenerated by injecting HABA-buffer (IBA, Göttingen, Germany).

\section{Isothermal Titration Calorimetry (ITC)}

ITC experiments were performed on a VP-ITC microcalorimeter (MicroCal, LCC) in buffer containing $10 \mathrm{mM}$ HEPES-NaOH, $\mathrm{pH} 7.4,50 \mathrm{mM} \mathrm{KCl}, 50 \mathrm{mM} \mathrm{NaCl}$ and $1 \mathrm{mM} \mathrm{MgCl}_{2}$ at $20^{\circ} \mathrm{C}$.

Isotherms of $2-\mathrm{OG}$ binding to $\mathrm{P}_{\mathrm{II}}$ (33 $\mu \mathrm{M}$ trimer concentration) were determined in the presence of various ATP/ADP ratios: $1 \mathrm{mM} / 0.25 \mathrm{mM}, 1 \mathrm{mM} / 0.5 \mathrm{mM}, 1 \mathrm{mM} / 1 \mathrm{mM}$ as well as only $1 \mathrm{mM}$ ATP or $1 \mathrm{mM}$ ADP. For one measurement $5 \mu \mathrm{l}$ of $2 \mathrm{mM}$ 2-OG was injected 35 times $(4.2-293.7 \mu \mathrm{M})$ to the measuring cell containing $\mathrm{P}_{\mathrm{II}}$ protein (cell volume $1.4285 \mathrm{ml}$ ) with stirring at $350 \mathrm{rpm}$. The binding isotherms were calculated from the recorded data and fitted to a one-site and a three-sites binding models using the MicroCal ORIGIN software (Northampton, USA) as indicated.

\section{Direct coupled NAGK activity assay}


The specific activity of NAGK from S. elongatus was assayed by coupling NAGK-dependent NAG phosphorylation to AGPR-catalyzed reduction of NAG-phosphate with NADPH as reductant and recording the change in absorbance at $340 \mathrm{~nm}$ [43]. The reaction buffer consisted of $50 \mathrm{mM}$ potassium phosphate buffer ( $\mathrm{pH} 7), 50 \mathrm{mM} \mathrm{KCl}, 20 \mathrm{mM} \mathrm{MgCl}_{2}, 0.2 \mathrm{mM} \mathrm{NADPH}$ and $0.5 \mathrm{mM}$ DTT. Each reaction contained $10 \mu \mathrm{g}$ AGPR, $50 \mathrm{mM} \mathrm{NAG}$ and $2.4 \mu \mathrm{g} \mathrm{P}_{\mathrm{II}}$ with $6 \mu \mathrm{g}$ NAGK or 1.2 $\mu \mathrm{g} \mathrm{P}_{\mathrm{II}}$ with $3 \mu \mathrm{g}$ NAGK. The metabolites ATP, ADP, arginine and 2-OG varied depending on the experiment being performed. The reaction was started by the addition of NAGK. Phosphorylation of one molecule of NAG leads to oxidation of one molecule of NADPH, which is followed by the linear decrease of absorbance at $340 \mathrm{~nm}$, recorded in a volume of $1 \mathrm{ml}$ over a period of 10 min with a SPECORD 200 photometer (Analytik Jena). One unit of NAGK catalyzes the conversion of 1 mmol NAG per min. The reaction velocity was calculated with a molar absorption coefficient of $\mathrm{NADH}$ of $\varepsilon_{340}=6178 \mathrm{~L} \mathrm{~mol}^{-1} \mathrm{~cm}^{-1}$ from the slope of the change of absorbance per time.

\section{$\mathbf{P}_{\mathrm{II}}-\mathrm{PipX}$ in vitro cross-linking}

$\mathrm{P}_{\mathrm{II}}$-PipX interaction was analyzed using glutardialdehyde cross-linking. $\mathrm{P}_{\mathrm{II}}(0.1 \mu \mathrm{g} / \mu \mathrm{l})$ was preincubated with PipX $(0.2 \mu \mathrm{g} / \mu \mathrm{l})$ in the absence or in the presence of effectors ATP, ADP and 2OG in $20 \mu \mathrm{l}$ buffer containing $10 \mathrm{mM}$ potassium phosphate buffer $\mathrm{pH} 7.4,100 \mathrm{mM} \mathrm{NaCl}$ and $2 \mathrm{mM}$ $\mathrm{MgCl}_{2}$ at $4^{\circ} \mathrm{C}$. After $5 \mathrm{~min}, 0.1 \%(\mathrm{w} / \mathrm{w})$ glutardialdehyde was added and the samples were incubated for $5 \mathrm{~min}$ at $25^{\circ} \mathrm{C}$. The cross-linking reaction was stopped by the addition of $100 \mathrm{mM}$ Tris- $\mathrm{HCl} \mathrm{pH}$ 7.4. The cross-link products were analyzed by $12.5 \%$ SDS-PAGE followed by immunoblot analysis with $\mathrm{P}_{\mathrm{II}}$-specific antibody as described previously [44].

\section{Results}

\section{Different ATP/ADP ratios affect the activation of NAGK by $P_{I I}$ and its relief from arginine inhibition}

The effect of different ADP/ATP ratios on the activation of NAGK by $\mathrm{P}_{\mathrm{II}}$ and on the $\mathrm{P}_{\mathrm{II}}$-mediated relief from arginine inhibition could not be determined in the previously used assay, in which ATP consumption was coupled to NADH oxidation. However, by assaying the activity of NAGK in a reaction, where the phosphorylation of NAG is linked to the subsequent reduction of NAGphosphate by AGPR with NADPH as a reductant [43], it is possible to determine the activity of NAGK under almost physiological conditions and at variable ATP/ADP levels. Increasing ATP concentrations from $0.5 \mathrm{mM}$ to $4 \mathrm{mM}$ enhanced the activity of NAGK both in the presence or absence of $\mathrm{P}_{\mathrm{II}}$ (Fig. 1a and b), which was expected from the $\mathrm{K}_{\mathrm{m}}$ of NAGK for ATP (without $\mathrm{P}_{\mathrm{II}}$ $\mathrm{K}_{\mathrm{m}}=0.6 \mathrm{mM}$, in the presence of $\mathrm{P}_{\mathrm{II}} \mathrm{K}_{\mathrm{m}}=1.1 \mathrm{mM}$ ) [36]. Addition of ADP monotonically reduced the activity of $\mathrm{P}_{\mathrm{II}}$-complexed NAGK at any fixed ATP concentration. The higher the ADP concentration was, the more decreased the activity of NAGK. At a low constant ATP concentration, the relative decrease in NAGK activity by ADP addition was more pronounced than at high constant ATP concentration (6.4-fold decrease from 0 to $4 \mathrm{mM}$ ADP at fixed $0.5 \mathrm{mM}$ ATP compared to 2.6-fold decrease from 0 to $4 \mathrm{mM}$ ADP at fixed $4 \mathrm{mM} \mathrm{ATP}$ ). At the highest ADP/ATP ratio (4 $\mathrm{mM}$ ADP with 0.5. $\mathrm{mM}$ ATP), NAGK activity in presence of $\mathrm{P}_{\mathrm{II}}$ was as low as NAGK activity in the absence of $\mathrm{P}_{\mathrm{II}}$ (Fig. 1a and b). In the absence of $\mathrm{P}_{\mathrm{II}}$, NAGK responded only weakly to different ATP/ADP ratios (Fig. 1b), with a 1.8-fold reduction of activity comparing 0 and $4 \mathrm{mM}$ ADP at any fixed ATP concentration. This indicates that the response of NAGK activity in presence of $\mathrm{P}_{\mathrm{II}}$ towards different ADP/ATP ratios operates through the adenylate binding properties of $\mathrm{P}_{\mathrm{II}}$.

In the AGPR-coupled assay, NAGK was more sensitive to arginine inhibition than in the previously reported pyruvate kinase (PK)/ lactate dehydrogenase (LDH) coupled assay [31, 36], which keeps the ATP level constant at $10 \mathrm{mM}$. Using the AGPR-coupled assay, $10 \mu \mathrm{M}$ arginine inhibited the free enzyme, but $\mathrm{P}_{\mathrm{II}}$ relieved NAGK from arginine inhibition (Fig. 2a), as described previously for 
the colorimetric assay and the PK/LDH coupled assay $[31,36]$. The inhibitory effect of ADP on NAGK in the presence of $\mathrm{P}_{\text {II }}$ was tested at different arginine concentrations $(20 \mu \mathrm{M}, 40 \mu \mathrm{M}$ and 60 $\mu \mathrm{M}$ ), which are completely inhibitory for free NAGK but not or only moderately inhibitory to $\mathrm{P}_{\mathrm{II}^{-}}$ complexed NAGK. In these experiments ATP was fixed at $2 \mathrm{mM}$. Arginine inhibition was efficiently relieved by $\mathrm{P}_{\mathrm{II}}$ in the presence of ATP alone; increasing concentrations of ADP increasingly diminished this effect, but didn't completely tune it down. If ADP would completely inhibit complex formation between $\mathrm{P}_{\mathrm{II}}$ and NAGK, full inhibition of NAGK would be expected at high ADP concentrations in the presence of arginine. The lack of full inhibition implies that ADP did not fully prevent $\mathrm{P}_{\mathrm{II}} \mathrm{NAGK}$ interaction in the presence of $2 \mathrm{mM}$ ATP.

2-OG is a key effector molecule in $\mathrm{P}_{\mathrm{II}}$ mediated signal transduction; micromolar amounts of 2-OG in the presence of ATP negatively affected $\mathrm{P}_{\mathrm{II}}-\mathrm{NAGK}$ complex formation [31]. Previous studies using the $\mathrm{PK} / \mathrm{LDH}$ coupled assay could demonstrate the inhibitory effect of 2-OG on $\mathrm{P}_{\mathrm{II}}-\mathrm{NAGK}$ interaction by antagonizing the protective effect of $\mathrm{P}_{\mathrm{II}}$ on NAGK activity in the presence of $50 \mu \mathrm{M}$ arginine. In a similar experimental setting using the AGPR-coupled assay, NAGK activity decreased 10-fold when the 2-OG concentration was increased from 0 to $250 \mu \mathrm{M}$ in the presence of $\mathrm{P}_{\mathrm{II}}, 30 \mu \mathrm{M}$ arginine and $2 \mathrm{mM}$ ATP (Fig. 2b). The apparent half maximal inhibitory concentration $\left(\mathrm{IC}_{50}\right)$ of 2-OG was estimated to be $78 \mu \mathrm{M}$, a similar result as obtained in the previous study [6]. To reveal, how ADP affects the response towards 2-OG, the same experiment was performed in the presence of $2 \mathrm{mM}$ ATP together with $2 \mathrm{mM}$ ADP (Fig. 2b). The activity at zero 2-OG was 3-times lower than in the control in the absence of ADP, and it decreased 5-fold by titrating 2-OG up to 250 $\mu \mathrm{M}$. The apparent $\mathrm{IC}_{50}$ for $2-\mathrm{OG}$ in the presence of $\mathrm{ADP}$ was at about $145 \mu \mathrm{M}$, showing that 2-OG inhibited $\mathrm{P}_{\mathrm{II}}$-NAGK complex formation also in the presence of $\mathrm{ADP}$, although moderately less efficiently.

\section{Inhibitory effect of ADP on 2-OG binding of $P_{I I}$ in the presence of ATP}

The 2-OG-binding site in $\mathrm{P}_{\mathrm{II}}$ is created by a $\mathrm{Mg}^{2+}$ ion, which is coordinated by the gammaphosphate of a bound ATP molecule and amino acid residues of one monomer of the $\mathrm{P}_{\mathrm{II}}$ trimer itself. Binding of a single 2-OG molecule to $\mathrm{P}_{\mathrm{II}}$ leads to a strong conformational change of the $\mathrm{T}$ loop extending from the subunit, which ligates 2-OG, and moreover, to subtle changes in the other two binding sites as a result of negative cooperativity [8]. 2-OG binding in the presence of ATP was already measured by Isothermal Titration Calorimetry and the raw data could be fitted to a three sequential binding site model, that revealed the anticooperative occupation of the three binding sites [6]. Since ADP and ATP compete for the same binding site, an ADP molecule bound to one monomer of $\mathrm{P}_{\mathrm{II}}$ might influence the affinity for 2-OG of the other two monomers because of the $\mathrm{P}_{\mathrm{II}}$ intersubunit communication. Therefore, we next studied the effect of ADP on the binding of 2-OG to $\mathrm{P}_{\mathrm{II}}$. The raw data were tried to fit according to a three sequential binding model, but were also fitted using a one binding site model, because in a mixture of ATP and ADP, the number of available 2-OG-binding sites in $\mathrm{P}_{\mathrm{II}}$ cannot be reliably predicted. Data fitting according to a model with three sequential binding sites could only be achieved for measurements done in excess of ATP over ADP (Table 1). At a molar ratio of 1:1 ADP/ATP, the binding isotherm was only consistent with the one-site model. Fitting to a one binding site model reveals a combined $\mathrm{K}_{\mathrm{d}}$ of all binding sites and a mean stoichiometry of bound ligands. As shown in Fig. 3a, 2-OG exhibited high affinity towards $P_{I I}$ in the presence of $1 \mathrm{mM}$ ATP. The combined $\mathrm{K}_{\mathrm{d}}$ of $39 \mu \mathrm{M}$ for all three binding sites was calculated from the binding isotherms of three independent experiments. On the other hand, in the presence of $\mathrm{Mg}^{2+}$-ADP, titration with 2-OG didn't yield any calorimetric signals (Fig. 3b), obviously because ADP is not able to create the 2-OG-binding site. To reveal how ADP affects the binding of 2-OG to $\mathrm{P}_{\mathrm{II}}$ in presence of ATP, 2-OG was titrated to various mixtures of ADP/ATP in presence of $\mathrm{P}_{\mathrm{II}}$. The addition of $0.25 \mathrm{mM}$ ADP to $1 \mathrm{mM}$ ATP (ADP/ATP ratio 1:4) had a negative effect on 2-OG binding (Fig 3c) with the apparent $\mathrm{K}_{\mathrm{d}}$ increasing to $78 \mu \mathrm{M}$ and the binding stoichiometry $(\mathrm{N})$ decreasing from 1.73 to 1.35 (Table 1). Increasing concentrations of ADP led to further increase of the $\mathrm{K}_{\mathrm{d}}$ for 2-OG binding and to a decrease in the binding stoichiometry (Fig $3 \mathrm{~d}$ 
and e, Table 1). In the presence of ATP alone, data fitting retrieved a mean stoichiometry of 1.732 OG molecules per $\mathrm{P}_{\mathrm{II}}$ trimer. Since each $\mathrm{P}_{\mathrm{II}}$ trimer has three binding sites for 2-OG, data fitting according to a one binding site model underestimates the actual number of binding sites, which could be due to the anticooperativity between the sites. The $\mathrm{N}$ value in the presence of $1 \mathrm{mM}$ ATP and $1 \mathrm{mM}$ ADP $(1: 1$ ratio, $\mathrm{N}=0.75)$ therefore indicates that one of the three binding sites can be efficiently occupied by 2-OG under theses conditions. Furthermore, ADP increases the $\mathrm{K}_{d}$ of the remaining 2-OG binding site to approximately $183 \mu \mathrm{M}$.

\section{Different ATP/ADP ratios alter the association and dissociation of the $P_{I I}$-NAGK complex}

As shown previously, ADP negatively affects $\mathrm{P}_{\mathrm{II}}$-NAGK interaction by increasing the dissociation of the complex [6]. To reveal in more detail how ADP affects $\mathrm{P}_{\mathrm{II}}-\mathrm{NAGK}$ association, $\mathrm{P}_{\mathrm{II}}$ was first loaded on the NAGK surface in the absence of effectors and was than eluted by injection of $1 \mathrm{mM}$ ADP (Fig. 4a, left). Subsequently, the same amount of $\mathrm{P}_{\mathrm{II}}$ was injected to the NAGK sensor surface in presence of $1 \mathrm{mM}$ ADP, which resulted again in rapid complex formation. At the end of injection, after an initial drop of resonance units, dissociation ceased. A further injection of $1 \mathrm{mM}$ ADP resulted again in rapid dissociation of bound $\mathrm{P}_{\mathrm{II}}$ (Fig. $4 \mathrm{a}$, right). Comparing the association curves shows that in presence of ADP, the curve reaches rapidly a plateau, which is approximately at one third of the maximal level obtained in absence of ADP. The steep initial increase of resonance units and rapid equilibration indicates that ADP enhances both the association and dissociation kinetics of $\mathrm{P}_{\mathrm{II}}$-NAGK complex formation. The fact that $\mathrm{P}_{\mathrm{II}}$-ADP didn't fully dissociate from NAGK after the end of the injection, but could again be rapidly dissociated after a further injection of ADP can be explained. At the end of the $\mathrm{P}_{\mathrm{II}}-\mathrm{ADP}$ injection, when the sensor ship is rinsed with $A D P$-free running buffer, $A D P$ from $\mathrm{P}_{\mathrm{II}}$ dissociates faster than $\mathrm{P}_{\mathrm{II}}$-ADP from NAGK, leaving ADP-free $\mathrm{P}_{\mathrm{II}}$, which can stay bound on NAGK.

The influence of various ADP/ATP ratios on $\mathrm{P}_{\mathrm{II}}-\mathrm{NAGK}$ interaction was investigated by injecting $\mathrm{P}_{\mathrm{II}}$ on a sensor-chip with immobilized NAGK in the presence of different concentrations of ADP and ATP and subsequently injecting the same buffer in the absence of $\mathrm{P}_{\mathrm{II}}$, to determine the ATP/ADPdependent dissociation of the complex (Fig. 4b). In the presence of ATP, rapid association of the $\mathrm{P}_{\mathrm{II}}$-NAGK was observed and injection of ATP to the complex didn't accelerate the dissociation. Addition of $1 \mathrm{mM}$ ADP to $2 \mathrm{mM}$ ATP had only a minor effect on complex formation (association was slightly faster and the maximal level slightly lower), but drastically accelerated complex dissociation (Fig. 4b). Higher concentrations of ADP (2 and $4 \mathrm{mM})$ at fixed $2 \mathrm{mM}$ ATP lowered the steady state binding equilibrium during the first injection phase and increased the dissociation velocity to reach the velocity caused by ADP alone. Remarkably, in the excess of ADP over ATP, there was clearly more $\mathrm{P}_{\mathrm{II}} \mathrm{NAGK}$ complex formation than with $\mathrm{ADP}$ alone, although complex dissociation was similarly fast in both cases.

\section{Affinity of PipX to $P_{I I}$ in the presence of ADP}

Three PipX monomers can bind to one $\mathrm{P}_{\text {II }}$ trimer in the absence of 2-OG [28]. However, at elevated 2-OG levels in the presence of ATP, $\mathrm{P}_{\mathrm{II}}$ PipX complex formation is impaired and free PipX can now bind to and activate the transcription factor NtcA [28]. These in vitro properties are correlated in vivo to nitrogen-limiting conditions. Here, we used SPR spectroscopy and glutardialdehyde cross-linking to determine the influence of ADP on 2-OG-modulated $\mathrm{P}_{\mathrm{II}}$-PipX complex formation.

In a first set of experiments, the $\mathrm{His}_{6}-\mathrm{PipX}$ was preincubated with homotrimeric Strep-tagged $\mathrm{P}_{\mathrm{II}}$ protein in the absence or in the presence of effectors and injected on the $\mathrm{Ni}^{2+}$-loaded NTA chip. To ensure that all $\mathrm{P}_{\mathrm{II}}$ trimers are fully occupied with PipX and enough free PipX is present, 5:1 $\mathrm{PipX} / \mathrm{P}_{\text {II }}$ monomer ratio was used. In a control binding experiment His ${ }_{6}$-PipX was loaded on the chip in the absence of $\mathrm{P}_{\mathrm{II}}$. PipX monomers alone showed relatively low binding to the chip due to the single short $\mathrm{His}_{6}$-tag and therefore reached the equilibrium fast and dissociated after the end of the injection from the surface (Figure S1). Effectors had no influence on the interaction of His $6^{-}$ PipX with $\mathrm{Ni}^{2+}$-loaded NTA chip surface. Addition of $\mathrm{P}_{\mathrm{II}}$ to PipX increased the binding signal in the sensorgram 2.5 times and decreased the dissociation rate, which can be explained by enhanced 
binding of the $\mathrm{P}_{\mathrm{II}}$-PipX complexes, containing three His ${ }_{6}$-tags that strongly bind to the surface, compared to monomeric PipX. $\mathrm{P}_{\mathrm{II}}$ in the absence of PipX didn't bind to the chip surface. Thus, the increase of resonance units induced by the addition of $\mathrm{P}_{\mathrm{II}}$ to PipX can be used to quantify $\mathrm{P}_{\mathrm{II}}$-PipX complex formation. Addition of $1 \mathrm{mM}$ ADP to $\mathrm{P}_{\mathrm{II}}$-PipX had a strong positive effect on the binding signal, probably due to the stabilization of the $\mathrm{P}_{\mathrm{II}}-\mathrm{PipX}$ interaction, allowing more protein complexes to bind to the chip (Figure S1). The experiment was repeated in the presence of different ATD/ADP ratios and 2-OG. The increase of resonance units $(\Delta \mathrm{RU})$ from the start to the end of the injection indicates the amount of protein binding to the chip surface. The $\Delta R U$ values $(a t t=197 \mathrm{~s})$ for the binding of PipX without $P_{I I}$ was subtracted from the $\Delta R U$ values obtained in the presence of $\mathrm{P}_{\mathrm{II}}$ and different effector molecules and the results are shown in the bar graph in Fig. 5a. In the absence of effectors the $\mathrm{P}_{\mathrm{II}}$-PipX complex binding reaches more than 800 RU. The amount of $\mathrm{P}_{\mathrm{II}^{-}}$ PipX complexes is enhanced by ADP and less efficiently by ATP; intermediate binding levels were obtained in a mixture of $1 \mathrm{mM}$ ATP and ADP. Figure 5a shows that 2-OG in the presence of ATP is a strong inhibitor of $\mathrm{P}_{\mathrm{II}}$-PipX complex formation, the binding levels were almost the same as for free PipX. ADP acted antagonistically to 2-OG, even small amounts of ADP $(0.05 \mathrm{mM})$ could significantly repress the 2-OG signal in the presence of $1 \mathrm{mM}$ ATP in vitro. The amount of $\mathrm{P}_{\mathrm{II}}$-PipX complex in the presence of $1 \mathrm{mM}$ ADP, ATP and 2-OG was even higher than in the absence of any effectors, showing that $1 \mathrm{mM}$ ADP can almost completely erase the inhibitory effect of 2-OG.

This result was confirmed in a $\mathrm{P}_{\mathrm{II}} \mathrm{PipX}$ binding assay, where proteins were preincubated under different conditions and cross-linked using glutardialdehyde. Subsequently, the products were visualized by SDS-PAGE and immunoblot analysis with $\mathrm{P}_{\mathrm{II}}$-specific antibody. As shown in Fig. 5b, in the absence of PipX, the cross-links of $\mathrm{P}_{\mathrm{II}}$ trimers are prevalent and the dimeric form was only only slightly visible, the single $\mathrm{P}_{\mathrm{II}}$ monomers were not present. Though in the presence of PipX alone no other bands were detected, with $1 \mathrm{mM}$ ADP one additional band was observed, with higher molecular mass than the $\mathrm{P}_{\mathrm{II}}$ trimer, consistent with a $\mathrm{P}_{\mathrm{II}}-\mathrm{PipX}$ cross-link product that could be formed, when ADP stabilized the complex. ATP had no such effect, but in the presence of both 1 $\mathrm{mM}$ ATP/ADP the characteristic band was also observed. In comparison to the SPR experiments, higher concentrations of ADP were needed to neutralize the negative effect of 2-OG.

The $\mathrm{P}_{\mathrm{II}}$-PipX interaction was also studied with C-terminal Strep-tagged $\mathrm{P}_{\mathrm{II}}$ protein immobilized on a Strep-Tactin II-coated sensor chip surface, where PipX was injected as an analyte. Immobilized $\mathrm{P}_{\mathrm{II}}$ protein was able to build a complex with PipX, but the interaction was insensitive to the effector molecules ATP and 2-OG (Fig. S2). We hypothesized, that by fixing the C-terminus of the $\mathrm{P}_{\mathrm{II}}$ subunits on the chip surface, the conformational change of the $\mathrm{C}$-terminus that occurs upon binding of ATP and 2-OG (a movement of the C-terminus towards the ATP-molecule) [8] is prevented and, therefore, the $\mathrm{P}_{\mathrm{II}}$-PipX complex was not affected by these effectors. To solve this question, a heterotrimeric Strep-tagged $\mathrm{P}_{\text {II }}$ protein was constructed by co-expressing Strep-tagged and untagged $\mathrm{P}_{\mathrm{II}}$ subunits und purifying heterotrimers containing only one or two Strep-tagged subunits. If the above-mentioned assumption was true, the untagged subunits should be able to respond to the effectors. Heterotrimeric $P_{I I}$ was fixed on the Step-Tactin-coated chip and PipX could bind to this surface as efficient as to the homotrimeric Strep-tagged $\mathrm{P}_{\mathrm{II}}$ protein (Fig. 5c). In contrast to the Strep-tagged $\mathrm{P}_{\mathrm{II}}$ homotrimer, the interaction was indeed weakened by $1 \mathrm{mM} 2-\mathrm{OG}$ in the presence of $2 \mathrm{mM} \mathrm{Mg}^{2+}$-ATP, although not completely, because of the remaining Strep-tagged $\mathrm{P}_{\mathrm{II}}$ subunits. Injection of PipX in the presence of $2 \mathrm{mM}$ ADP on the immobilized heterotrimeric $\mathrm{P}_{\mathrm{II}}$ showed an enhanced velocity of complex association compared to binding in the absence of effector molecules. Furthermore, ADP was able to antagonize the negative effect of 2-OG on PipX-P $\mathrm{P}_{\text {II }}$ binding: when ADP was added to a mixture of ATP and 2-OG, more PipX could bind to the $\mathrm{P}_{\mathrm{II}}$ surface than in the absence of ADP.

\section{Discussion}


An important feature of cyanobacterial $\mathrm{P}_{\mathrm{II}}$ signal transduction is the sensing of the balance of carbon and nitrogen status through binding of the central metabolite 2-OG. Results, presented here, indicate how $\mathrm{P}_{\mathrm{II}}$ could also act as a sensor of adenylate energy charge in cyanobacteria. Binding of 2-OG to the ATP-ligated $\mathrm{P}_{\mathrm{II}}$ protein is the fundament of $\mathrm{P}_{\mathrm{II}}$-mediated signal transduction. ADP was shown to occupy the ATP-site of $\mathrm{P}_{\text {II }}$ proteins $[3,14,15]$. Therefore, ADP binding prevents the coordination of the bridging $\mathrm{Mg}^{2+}$ ion by the $\gamma$-phosphate of ATP, which is essential for 2-OG binding [8]. In accord, no binding of 2-OG to ADP-occupied S. elongatus $\mathrm{P}_{\text {II }}$ protein occurs. When ATP and ADP are present simultaneously, as is the case in living cells, there will be competition for the three adenylate binding sites of the trimeric $\mathrm{P}_{\text {II }}$ protein. Moreover, it has to be considered, that the three binding sites are interacting in an anticooperative manner. In contrast to the E.coli system, where ADP binds better than ATP [3], the affinity of each of the three binding sites of the cyanobacterial $\mathrm{P}_{\mathrm{II}}$ towards $\mathrm{ADP}\left(\mathrm{K}_{\mathrm{d}}\right.$ of 10,19 and $\left.133 \mu \mathrm{M}\right)$ is approximately 2-3 fold lower than towards ATP $\left(\mathrm{K}_{\mathrm{d}}\right.$ of 4,12 and $\left.47 \mu \mathrm{M}\right)$ [6]. So, when $\mathrm{P}_{\mathrm{II}}$ is exposed to a mixture of ATP and ADP, a mixed occupation of the adenylate binding sites is expected with a concomitant decreased capability to bind 2-OG. In agreement, the number of 2-OG binding sites per $\mathrm{P}_{\mathrm{II}}$ trimer was reduced by the addition of ADP. As long as ATP stayed in excess over ADP, the 2-OG binding process could be fitted according to a three sequential binding model, but the average number of 2-OG-binding sites in the mixed population of $\mathrm{P}_{\mathrm{II}}$ trimers decreased. This indicates that part of the $\mathrm{P}_{\mathrm{II}}$ population didn't exhibit three 2-OG binding sites anymore. This part of the population has probably at least one ADP molecule bound. Furthermore, the affinity for 2-OG binding decreases. At a 1:1 molar ratio of ADP to ATP, the dominating $P_{I I}$ population should consist of $P_{I I}$ trimers with a mixed occupation of ATP and ADP. Considering the 2-3-higher affinity for ATP, the $\mathrm{P}_{\text {II }}$ species $\mathrm{P}_{\mathrm{II}}-\mathrm{ATP}_{2} \mathrm{ADP}_{1}$ should clearly prevail over the species $\mathrm{P}_{\mathrm{II}}-\mathrm{ATP}_{1} \mathrm{ADP}_{2}$. Under these conditions, on average, only one 2-OG molecule can apparently bind to $\mathrm{P}_{\mathrm{II}}$. The binding process can no more be fitted according to a three sequential binding site model. The affinity of the remaining 2-OG-binding site seems to be as low as that of the third, low-affinity 2-OG-binding site of ATP-ligated $\mathrm{P}_{\text {II }}$ (Tab. 1). This implies that binding of $\mathrm{ADP}$ to one site in $\mathrm{P}_{\mathrm{II}}$ has a strong negative effect for the remaining 2-OG-binding sites, so that probably only one site can be efficiently occupied. The binding of 2-OG to the lowest affinity site appears to be crucial for inhibition of $\mathrm{P}_{\mathrm{II}}-\mathrm{NAGK}$ interaction, since the $\mathrm{IC}_{50}$ of 2-OG at a 1:1 ratio of ADP to ATP $(145 \mu \mathrm{M})$ for inhibiting $\mathrm{P}_{\mathrm{II}}-\mathrm{NAGK}$ interaction is near the $\mathrm{K}_{\mathrm{d}}$ measured for 2-OG binding at the same ADP/ATP concentrations $(183 \mu \mathrm{M})$. This mechanism allows the $\mathrm{P}_{\mathrm{II}^{-}}$ NAGK complex to stay sensitive towards $2-0$ G under low energy conditions.

The ADP-ligated $\mathrm{P}_{\text {II }}$ protein appears to be able to bind to NAGK, but binding is clearly different for that of ATP-ligated $\mathrm{P}_{\mathrm{II}}$, as revealed by SPR spectroscopy. In particular, the dissociation rate of the $\mathrm{P}_{\mathrm{II}}$-NAGK complex was highly increased by ADP. The increased dissociation rate results in a lower steady state binding level of $\mathrm{P}_{\mathrm{II}}$-ADP to NAGK. $\mathrm{P}_{\mathrm{II}}$-species occupied with a mixture of ATP and ADP display intermediate binding properties: At 1:2 and 2:2 $\mathrm{mM}$ mixtures of ADP/ATP, the $\mathrm{P}_{\mathrm{II}^{-}}$ $\mathrm{ATP}_{2} \mathrm{ADP}_{1}$ species should prevail. These conditions already lead to enhanced complex dissociation. In mixtures of $3: 2$ or $4: 2 \mathrm{mM}$ ADP/ATP, more and more of the $\mathrm{P}_{\mathrm{II}}-\mathrm{ATP}_{1} \mathrm{ADP}_{2}$ species should appear, however, fully ADP-ligated $\mathrm{P}_{\mathrm{II}}$ species are very unlikely. In accord, the binding curves under these two conditions were very similar towards each other and distinct from that of fully ADP-ligated $\mathrm{P}_{\mathrm{II}}$ with NAGK.

We have previously suggested a two-step model for the binding of $\mathrm{P}_{\mathrm{II}}$ to NAGK [6]. Following a transient encounter complex involving B-loop residues of $\mathrm{P}_{\mathrm{II}}$, the $\mathrm{T}$-loop folds into a compact conformation, which tightly associates with NAGK. In ADP-ligated $\mathrm{P}_{\text {II }}$ protein, the T-loop may be impaired in folding into the perfect NAGK-binding conformation, explaining the fast dissociation of the complex. Measuring NAGK activity in mixtures of ATP, ADP and $\mathrm{P}_{\text {II }}$ suggests that $\mathrm{P}_{\mathrm{II}}$ protein occupied with ATP/ADP mixtures is unable to enhance the catalytic activity of NAGK. On the other hand, NAGK, which forms a complex with ATP/ADP-occupied $\mathrm{P}_{\mathrm{II}}$ is protected from arginine inhibition as efficient as by purely ATP-occupied $\mathrm{P}_{\mathrm{II}}$. These properties suggest that protection from arginine inhibition and activation of catalytic activity of NAGK by $\mathrm{P}_{\mathrm{II}}$ operates by 
different mechanisms: The loose binding of ATP/ADP-ligated $\mathrm{P}_{\mathrm{II}}$ to NAGK is sufficient to relieve arginine inhibition, but is insufficient to rearrange the catalytic centre of NAGK, resulting in enhanced activity. This suggestion is in accord with two different contact surfaces of $\mathrm{P}_{\text {II }}$ with NAGK [35]. The rearrangement of the catalytic centre of NAGK by $\mathrm{P}_{\mathrm{II}}$ has been shown to require a tight hydrogen-bonding and ion-pair network involving the distal part of the T-loop of $\mathrm{P}_{\mathrm{II}}$ and the N-domain of NAGK, tightening the catalytic centre of NAGK [35]. The inability of ATP/ADPligated $\mathrm{P}_{\mathrm{II}}$ to enhance NAGK activity is thus in accord with the lax binding of this $\mathrm{P}_{\mathrm{II}}$ species, probably mediated by imperfect fit of the T-loop to the corresponding NAGK recognition site. By contrast, the relief from arginine inhibition appears to be mediated by the C-terminus of NAGK [36], interacting with the body of the $\mathrm{P}_{\text {II }}$ protein. In essence, NAGK complexed to partially ADPligated $\mathrm{P}_{\mathrm{II}}$ is not catalytically induced but still relived from feedback inhibition by arginine. In such a state, $\mathrm{P}_{\mathrm{II}}$-complexed NAGK wouldn't support elevated arginine synthesis for efficient nitrogen storage but could quickly respond to increasing energy levels.

PipX is another known partner of $\mathrm{P}_{\mathrm{II}}$ protein in $S$. elongatus. It switches between binding to $\mathrm{P}_{\text {II }}$ or NtcA, depending on the 2-OG concentration. Low adenylate energy charge (increased ADP/ATP ratio) enhances the association of the $\mathrm{P}_{\mathrm{II}} \mathrm{PipX}$ complex in vitro, thereby antagonizing the signal of nitrogen limitation (elevated 2-OG levels). $\mathrm{P}_{\mathrm{II}}$-PipX complex formation is highly ADP-sensitive; ADP promotes complex formation and protects it from dissociation by $2-\mathrm{OG}$ in vitro. Therefore, increasing ADP levels should decrease the activation of NtcA-dependent genes, which depends of PipX-NtcA interaction, due to efficient competition of $\mathrm{P}_{\text {II }}$ for PipX. Remarkably, the negative effect of 2-OG on $\mathrm{P}_{\mathrm{II}}-\mathrm{PipX}$ interaction was absent when Strep-tagged $\mathrm{P}_{\mathrm{II}}$ was fixed with its C-terminus to the sensor surface but could partially be restored with heterotrimeric Strep-tagged $\mathrm{P}_{\mathrm{II}}$, which consists partially of untagged monomers with a free C-terminus. Although $\mathrm{P}_{\mathrm{II}}$-PipX binding itself doesn't involve conformational changes on the $\mathrm{C}$-terminus of $\mathrm{P}_{\mathrm{II}}$, the movement of the C-terminus imposed by 2-OG binding is essential for the response to the effector molecules and incorporating metabolic signals $[8,9]$. Together, this study shows how the $S$. elongatus $\mathrm{P}_{\mathrm{II}}$ signal transduction protein is capable to respond in a fine-tuned manner to the change of the energy charge in vitro. Through $\mathrm{P}_{\mathrm{II}}$-dependent adenylate energy signalling, increasing ADP levels should diminish the NtcA-dependent activation of genes required for nitrogen assimilation under nitrogen-limiting conditions (high 2-OG levels). On the other hand, under nitrogen-excess conditions (low 2-OG levels), increased ADP levels, via $\mathrm{P}_{\Pi I}$ signalling, should diminish the activation of NAGK, thereby reducing the flux into the arginine biosynthesis pathway. In both cases, $\mathrm{P}_{\mathrm{II}}$-dependent signalling of increased ADP levels should dampen energetically expensive anabolic reactions. Comparing the response of PipX and NAGK to EC signalling by $\mathrm{P}_{\mathrm{II}}$, it appears that PipX is more sensitive towards low ADP levels.

The ability to bind 2-OG and adenyl nucleotides is conserved among $\mathrm{P}_{\text {II }}$ proteins in all three domains of life. Several studies indicated the involvement of $\mathrm{P}_{\mathrm{II}}$ in sensing the energy status in various bacteria. It was suggested that $\mathrm{P}_{\mathrm{II}}$ proteins in photosynthetic Proteobacterium Rhodospirillum rubrum responds to the cellular energy charge [22, 45]. Mutants of Rhodospirillum rubrum with impaired purine synthesis pathway were created and than provided with an exogenous adenine source to test the effect of different cellular ATP levels on $\mathrm{P}_{\mathrm{II}}$ signal transduction. However, depleted ATP levels had little effect on $\mathrm{P}_{\mathrm{II}}$-mediated regulation of NifA and nitrogenase activity. It was suggested that the ADP/ATP ratio states the actual signal for $\mathrm{P}_{\text {II }}$ protein, but the direct effect of ADP/ATP ratios has not been shown yet [5]. Jiang and Ninfa showed for the first time with reconstituted signal transduction systems using the E. coli $\mathrm{P}_{\mathrm{II}}$ protein and its receptors $\mathrm{NtrB}$, ATase and UTase/UR, that ADP affected almost all signalling properties of E. coli $\mathrm{P}_{\mathrm{II}}$ by antagonizing 2OG mediated responses $[3,18]$. The metabolite sensing involves intersubunit signalling in the $\mathrm{P}_{\mathrm{II}}$ trimer itself with cooperation of the multiple effector binding sites [19]. Furthermore, ADP antagonized the inhibitory effect of 2-oxoglutarate on the binding of the $\mathrm{P}_{\text {II }}$ paralogue GlnK to the AmtB ammonium transport protein in E. coli [7]. The present study extends these insights: in the 
case of the cyanobacterial system, ADP does not always antagonize the 2-OG signal but differentially affects the interaction of $\mathrm{P}_{\mathrm{II}}$ with its targets. ADP modulates $\mathrm{P}_{\mathrm{II}}$ signalling to the receptor NAGK primarily at low 2-OG levels without antagonizing the effect of 2-OG, whereas it antagonizes the inhibitory effect of $2-\mathrm{OG}$ for $\mathrm{P}_{\mathrm{II}} \mathrm{PipX}$ interaction. There is still discussion on how much unbound ATP is available in the cell at any given moment [46], but it appears that the ratio of ADP to ATP instead of the absolute concentration of ATP affects $\mathrm{P}_{\mathrm{II}}$ signal transduction. Further studies using in vivo systems could shed light on the physiological impact of this remarkable and complex signalling system. 


\section{Acknowledgements}

We thank Christopher Schuster and Sebastian Kindermann for their help in creating the heterotrimeric Strep-tagged $\mathrm{P}_{\mathrm{II}}$ protein.

\section{Funding}

This work was supported by DFG grant Fo195/10.

\section{Numbered references}

1 Chapman, A. G., Fall, L. and Atkinson, D. E. (1971) Adenylate energy charge in Escherichia coli during growth and starvation. J. Bacteriol. 108, 1072-1086

2 Franzen, J. S. and Binkley, S. B. (1961) Comparison of the acid-soluble nucleotides in Escherichia coli at different growth rates. J. Biol. Chem. 236, 515-519

3 Jiang, P. and Ninfa, A. J. (2007) Escherichia coli $\mathrm{P}_{\mathrm{II}}$ signal transduction protein controlling nitrogen assimilation acts as a sensor of adenylate energy charge in vitro. Biochemistry. 46, 12979-12996

4 Forchhammer, K. (2008) P(II) signal transducers: novel functional and structural insights. Trends Microbiol. 16, $65-72$

5 Zhang, Y., Pohlmann, E. L. and Roberts, G. P. (2009) Effect of perturbation of ATP level on the activity and regulation of nitrogenase in Rhodospirillum rubrum. J. Bacteriol. 191, 5526-5537

6 Fokina, O., Chellamuthu, V. R., Zeth, K. and Forchhammer, K. (2010) A Novel Signal Transduction Protein P(II) Variant from Synechococcus elongatus PCC 7942 Indicates a Two-Step Process for NAGK-P(II) Complex Formation. J. Mol. Biol. 399, 410-421

7 Radchenko, M. V., Thornton, J. and Merrick, M. (2010) Control of AmtB-GlnK complex formation by intracellular levels of ATP, ADP, and 2-oxoglutarate. J. Biol. Chem. 285, 31037-31045

8 Fokina, O., Chellamuthu, V. R., Forchhammer, K. and Zeth, K. (2010) Mechanism of 2-oxoglutarate signaling by the Synechococcus elongatus $\mathrm{P}_{\mathrm{II}}$ signal transduction protein. Proc. Natl. Acad. Sci. U. S. A. 107, 19760-19765

9 Truan, D., Huergo, L. F., Chubatsu, L. S., Merrick, M., Li, X. D. and Winkler, F. K. (2010) A new P(II) protein structure identifies the 2-oxoglutarate binding site. J. Mo1. Biol. 400, 531-539

10 Ninfa, A. J. and Jiang, P. (2005) $\mathrm{P}_{\mathrm{II}}$ signal transduction proteins: sensors of alpha-ketoglutarate that regulate nitrogen metabolism. Curr. Opin. Microbiol. 8, 168-173

11 Leigh, J. A. and Dodsworth, J. A. (2007) Nitrogen regulation in bacteria and archaea. Annu. Rev. Microbiol. 61, 349-377

12 Sant'Anna, F. H., Trentini, D. B., de Souto Weber, S., Cecagno, R., da Silva, S. C. and Schrank, I. S. (2009) The $\mathrm{P}_{\mathrm{II}}$ superfamily revised: a novel group and evolutionary insights. J. Mol. Evol. 68, 322-336

13 Forchhammer, K. (2004) Global carbon/nitrogen control by $\mathrm{P}_{\mathrm{II}}$ signal transduction in cyanobacteria: from signals to targets. FEMS Microbiol. Rev. 28,319-333

14 Xu, Y., Cheah, E., Carr, P. D., van Heeswijk, W. C., Westerhoff, H. V., Vasudevan, S. G. and Ollis, D. L. (1998) GlnK, a $P_{\mathrm{II}}$-homologue: structure reveals ATP binding site and indicates how the T-loops may be involved in molecular recognition. J. Mol. Biol. 282, 149-165

15 Xu, Y., Carr, P. D., Clancy, P., Garcia-Dominguez, M., Forchhammer, K., Florencio, F., Vasudevan, S. G., Tandeau de Marsac, N. and Ollis, D. L. (2003) The structures of the $\mathrm{P}_{\text {II }}$ proteins from the cyanobacteria Synechococcus sp. PCC 7942 and Synechocystis sp. PCC 6803. Acta. Crystallogr. D. Biol. Crystallogr. 59, 2183-2190

16 Sakai, H., Wang, H., Takemoto-Hori, C., Kaminishi, T., Yamaguchi, H., Kamewari, Y., Terada, T., Kuramitsu, S., Shirouzu, M. and Yokoyama, S. (2005) Crystal structures of the signal transducing protein GlnK from Thermus thermophilus HB8. J. Struct. Biol. 149, 99-110

17 Forchhammer, K. and Hedler, A. (1997) Phosphoprotein $\mathrm{P}_{\mathrm{II}}$ from cyanobacteria--analysis of functional conservation with the $\mathrm{P}_{\mathrm{II}}$ signal-transduction protein from Escherichia coli. Eur. J. Biochem. 244, 869-875 18 Jiang, P. and Ninfa, A. J. (2009) Alpha-Ketoglutarate Controls the Ability of the Escherichia coli $\mathrm{P}_{\mathrm{II}}$ Signal Transduction Protein To Regulate the Activities of NRII (NtrB) but Does Not Control the Binding of $P_{\text {II }}$ to NRII. Biochemistry. 48, 11514-11521

19 Jiang, P. and Ninfa, A. J. (2009) Sensation and Signaling of alpha-Ketoglutarate and Adenylylate Energy Charge by the Escherichia coli $\mathrm{P}_{\mathrm{II}}$ Signal Transduction Protein Require Cooperation of the Three Ligand-Binding Sites within the $\mathrm{P}_{\mathrm{II}}$ Trimer. Biochemistry. 48, 11522-11531

20 Smith, C. S., Weljie, A. M. and Moorhead, G. B. (2003) Molecular properties of the putative nitrogen sensor $\mathrm{P}_{\mathrm{II}}$ from Arabidopsis thaliana. Plant J. 33, 353-360

21 Zhang, Y., Pohlmann, E. L., Halbleib, C. M., Ludden, P. W. and Roberts, G. P. (2001) Effect of P(II) and its homolog GlnK on reversible ADP-ribosylation of dinitrogenase reductase by heterologous expression of the Rhodospirillum rubrum dinitrogenase reductase ADP-ribosyl transferase-dinitrogenase reductase-activating glycohydrolase regulatory system in Klebsiella pneumoniae. J. Bacteriol. 183, 1610-1620 
22 Zhang, Y., Pohlmann, E. L., Ludden, P. W. and Roberts, G. P. (2001) Functional characterization of three GlnB homologs in the photosynthetic bacterium Rhodospirillum rubrum: roles in sensing ammonium and energy status. J. Bacteriol. 183, 6159-6168

23 Zhang, Y. P., Pohlmann, E. L., Ludden, P. W. and Roberts, G. P. (2003) Regulation of nitrogen fixation by multiple P-II homologs in the photosynthetic bacterium Rhodospirillum rubrum. Symbiosis. 35, 85-100

24 Kloft, N. and Forchhammer, K. (2005) Signal transduction protein P-II phosphatase PphA is required for lightdependent control of nitrate utilization in Synechocystis sp strain PCC 6803. Journal of Bacteriology. 187, 6683-6690 25 Takatani, N., Kobayashi, M., Maeda, S. I. and Omata, T. (2006) Regulation of nitrate reductase by nonmodifiable derivatives of $\mathrm{P}_{\mathrm{II}}$ in the cells of Synechococcus elongatus strain PCC 7942. Plant and Cell Physiology. 47, $1182-1186$

26 Espinosa, J., Forchhammer, K., Burillo, S. and Contreras, A. (2006) Interaction network in cyanobacterial nitrogen regulation: PipX, a protein that interacts in a 2-oxoglutarate dependent manner with $\mathrm{P}_{\mathrm{II}}$ and NtcA. Mol. Microbiol. 61, 457-469

27 Espinosa, J., Forchhammer, K. and Contreras, A. (2007) Role of the Synechococcus PCC 7942 nitrogen regulator protein PipX in NtcA-controlled processes. Microbiology-Sgm. 153, 711-718

28 Llacer, J. L., Espinosa, J., Castells, M. A., Contreras, A., Forchhammer, K. and Rubio, V. (2010) Structural basis for the regulation of NtcA-dependent transcription by proteins PipX and $\mathrm{P}_{\mathrm{II}}$. Proc. Natl. Acad. Sci. U. S. A. 107, 15397-15402

29 Burillo, S., Luque, I., Fuentes, I. and Contreras, A. (2004) Interactions between the nitrogen signal transduction protein $\mathrm{P}_{\mathrm{II}}$ and $\mathrm{N}$-acetyl glutamate kinase in organisms that perform oxygenic photosynthesis. J. Bacteriol. 186, 3346-3354

$30 \quad$ Heinrich, A., Maheswaran, M., Ruppert, U. and Forchhammer, K. (2004) The Synechococcus elongatus P signal transduction protein controls arginine synthesis by complex formation with N-acetyl-L-glutamate kinase. Mol. Microbiol. 52, 1303-1314

31 Maheswaran, M., Urbanke, C. and Forchhammer, K. (2004) Complex formation and catalytic activation by the $\mathrm{P}_{\mathrm{II}}$ signaling protein of N-acetyl-L-glutamate kinase from Synechococcus elongatus strain PCC 7942. J. Biol. Chem. 279, 55202-55210

32 Chen, Y. M., Ferrar, T. S., Lohmeier-Vogel, E. M., Morrice, N., Mizuno, Y., Berenger, B., Ng, K. K. S., Muench, D. G. and Moorhead, G. B. G. (2006) The $\mathrm{P}_{\mathrm{II}}$ signal transduction protein of Arabidopsis thaliana forms an arginine-regulated complex with plastid N-acetyl glutamate kinase.(vol 281, pg 5726, 2006). Journal of Biological Chemistry. 281, 24084-24084

33 Bourrellier, A. B. F., Valot, B., Guillot, A., Ambard-Bretteville, F., Vidal, J. and Hodges, M. (2010) Chloroplast acetyl-CoA carboxylase activity is 2-oxoglutarate-regulated by interaction of $\mathrm{P}_{\mathrm{II}}$ with the biotin carboxyl carrier subunit. Proc. Natl. Acad. Sci. U. S. A. 107, 502-507

34 Mizuno, Y., Moorhead, G. B. and Ng, K. K. (2007) Structural basis for the regulation of N-acetylglutamate kinase by $\mathrm{P}_{\mathrm{II}}$ in Arabidopsis thaliana. J. Biol. Chem. 282, 35733-35740

35 Llacer, J. L., Contreras, A., Forchhammer, K., Marco-Marin, C., Gil-Ortiz, F., Maldonado, R., Fita, I. and Rubio, V. (2007) The crystal structure of the complex of $\mathrm{P}_{\mathrm{II}}$ and acetylglutamate kinase reveals how $\mathrm{P}_{\mathrm{II}}$ controls the storage of nitrogen as arginine. Proc. Natl. Acad. Sci. U. S. A. 104, 17644-17649

36 Beez, S., Fokina, O., Herrmann, C. and Forchhammer, K. (2009) N-acetyl-L-glutamate kinase (NAGK) from oxygenic phototrophs: P(II) signal transduction across domains of life reveals novel insights in NAGK control. J. Mol. Biol. 389, 748-758

37 Forchhammer, K. and Demarsac, N. T. (1995) Functional-Analysis of the Phosphoprotein P-Ii (Glnb GeneProduct) in the Cyanobacterium Synechococcus Sp Strain Pcc-7942. Journal of Bacteriology. 177, 2033-2040

38 Forchhammer, K. and Demarsac, N. T. (1995) Phosphorylation of the P-Ii Protein (Glnb Gene-Product) in the Cyanobacterium Synechococcus Sp Strain Pcc-7942 - Analysis of in vitro Kinase-Activity. Journal of Bacteriology. 177, 5812-5817

39 Ruppert, U., Irmler, A., Kloft, N. and Forchhammer, K. (2002) The novel protein phosphatase PphA from Synechocystis PCC 6803 controls dephosphorylation of the signalling protein P-II. Molecular Microbiology. 44, 855864

40 Forchhammer, K., Irmler, A., Kloft, N. and Ruppert, U. (2004) P-II signalling in unicellular cyanobacteria: analysis of redox-signals and energy charge. Physiologia Plantarum. 120, 51-56

41 Bueno, R., Pahel, G. and Magasanik, B. (1985) Role of $g \ln B$ and $g \ln D$ gene products in regulation of the glnALG operon of Escherichia coli. J. Bacteriol. 164, 816-822

42 Studier, F. W., Rosenberg, A. H., Dunn, J. J. and Dubendorff, J. W. (1990) Use of T7 RNA polymerase to direct expression of cloned genes. Methods Enzymol. 185, 60-89

43 Takahara, K., Akashi, K. and Yokota, A. (2007) Continuous spectrophotometric assays for three regulatory enzymes of the arginine biosynthetic pathway. Analytical Biochemistry. 368, 138-147

44 Forchhammer, K. and Demarsac, N. T. (1994) The P-Ii Protein in the Cyanobacterium Synechococcus Sp Strain Pcc-7942 Is Modified by Serine Phosphorylation and Signals the Cellular N-Status. Journal of Bacteriology. 176, 84-91 
45 Zhang, Y., Wolfe, D. M., Pohlmann, E. L., Conrad, M. C. and Roberts, G. P. (2006) Effect of AmtB homologues on the post-translational regulation of nitrogenase activity in response to ammonium and energy signals in Rhodospirillum rubrum. Microbiology. 152, 2075-2089

46 Schneider, D. A. and Gourse, R. L. (2004) Relationship between growth rate and ATP concentration in Escherichia coli - A bioassay for available cellular ATP. Journal of Biological Chemistry. 279, 8262-8268 


\section{Figure legends}

\section{Figure 1 Effect of ADP on NAGK activity in the AGPR-coupled assay}

Assay was performed in the presence of ATP at a concentration of $4 \mathrm{mM}$ (dashed line), $2 \mathrm{mM}$ (solid line), $1 \mathrm{mM}$ (dotted line) and $0.5 \mathrm{mM}$ (dot-dashed line), as indicated. AGPR-coupled NAGK assays were performed as described in Experimental. The percents of NAGK activity were plotted against the respective analyte concentration (standard deviations from the different measurements for each data point are indicated by error bars) and the data points were fitted to a hyperbolic curve (a) Enzyme activity with $\mathrm{P}_{\text {II }}$ protein (b) Effect on NAGK without $\mathrm{P}_{\mathrm{II}}$.

\section{Figure 2 Arginine inhibition and antagonistic effect of 2-OG on the NAGK activation by $P_{I I}$ in} the presence of arginine

AGPR-coupled NAGK assays were performed as described in Experimental. The percents of the NAGK activity were plotted against the respective analyte concentration (standard deviations from the different measurements for each data point are indicated by error bars) and the data points were fitted to a hyperbolic curve (a) ADP enhances inhibition of the NAGK activity by arginine in the presence of $2 \mathrm{mM}$ ATP. NAGK activity in the absence of $\mathrm{P}_{\mathrm{II}}$ and ADP (solid line), in the presence of $\mathrm{P}_{\mathrm{II}}$ : without ADP (dashed line), with $0.5 \mathrm{mM}$ ADP (dotted line), with $1 \mathrm{mM}$ ADP (thin solid line), with $2 \mathrm{mM}$ ADP (dot-dashed line), with $4 \mathrm{mM}$ ADP (dot-dot-dashed line). NAGK activity in the absence $\mathrm{P}_{\mathrm{II}}$ and arginine (dot-dashed line) (b) 2-OG effect on NAGK induction by $\mathrm{P}_{\mathrm{II}}$ in the presence of $2 \mathrm{mM}$ ATP and $30 \mu \mathrm{M}$ arginine without ADP (solid line) and with $2 \mathrm{mM}$ ADP (dashed line).

\section{Figure 3 ITC measurement of the 2-OG binding to $P_{I I}$ protein}

The upper panels show the raw data in the form of the heat effect during the titration of $33 \mu \mathrm{M} \mathrm{P}_{\mathrm{II}}$ solution (trimer concentration) with $2 \mathrm{mM}$ 2-OG. The lower panels show the binding isotherm and the best-fit curve according to the one-site binding model (a) 2-OG binding (titration 4.2-293.7 $\mu \mathrm{M}$ ) in the presence of $1 \mathrm{mM}$ ATP (b) 2-OG binding in the presence of $1 \mathrm{mM}$ ADP (c), (d) and (e) 2-OG binding in the presence of $1 \mathrm{mM}$ ATP and $0.25 \mathrm{mM}$ (C), $0.5 \mathrm{mM}$ (D), $1 \mathrm{mM}$ (E) ADP.

Figure 4 SPR analysis of the ADP/ATP ratio influence on the association and the dissociation of the $P_{\text {II-NAGK complex }}$

NAGK was bound to FC2 of a Ni ${ }^{2+}$-loaded NTA sensor chip (see Experimental) and FC1 was used as a background control. The response difference $(\triangle R U)$ between FC1 and FC2 is shown (a) Effect of $1 \mathrm{mM}$ ADP on the dissociation of wt $\mathrm{P}_{\mathrm{II}}$-NAGK complex following association without effectors (left) and in the presence of $1 \mathrm{mM}$ ADP (right) (b) Association and dissociation of $\mathrm{P}_{\mathrm{II}} \mathrm{NAGK}$ complex under influence of different ADP/ATP ratios: $2 \mathrm{mM}$ ATP (solid line), $2 \mathrm{mM}$ ATP $+1 \mathrm{mM}$ ADP (dotted line), $2 \mathrm{mM} \mathrm{ATP}+2 \mathrm{mM}$ ADP (short dashed line), $2 \mathrm{mM}$ ATP $+4 \mathrm{mM}$ ADP (long dashed line) and $2 \mathrm{mM}$ ADP (dot-dashed line).

\section{Figure 5 Effect of ATP, ADP and 2-OG on $P_{I I}$-PipX complex formation}

(a) His $_{6}$-PipX (500 nM) was preincubated with homotrimeric Strep- $\mathrm{P}_{\mathrm{II}}(100 \mathrm{nM})$ in the absence or in the presence of effectors, as indicated, and injected on the $\mathrm{Ni}^{2+}$-loaded NTA chip for SPR detection. As a control, His 6 -PipX was injected under the same conditions, but in the absence of $\mathrm{P}_{\mathrm{II}}$. The response signal at $t=197 \mathrm{~s}$ after start of the injection phase was taken as a measure of protein binding. The binding of $\mathrm{His}_{6}$-PipX alone was subtracted from the results measured in the presence of $\mathrm{P}_{\mathrm{II}}$. Error bars indicate standard deviations from the three independent measurements. (b) $\mathrm{P}_{\text {II }}{ }^{-}$ PipX binding assay using the glutardialdehyde cross-linking in vitro. $\mathrm{P}_{\text {II }}$ was preincubated with PipX in the presence and in the absence of effectors, as indicated, and subsiqently cross-linked using glutardialdehyde. The cross-link products were analyzed by SDS-PAGE followed by immunoblot analysis with $\mathrm{P}_{\mathrm{II}}$-specific antibody. (c) Effect of ADP, ATP and 2-OG on PipX binding to immobilized heterotrimeric Strep-tagged $\mathrm{P}_{\mathrm{II}}$ protein. $\mathrm{P}_{\mathrm{II}}(3.2 \mu \mathrm{M})$ was bound to FC2 of a CM5 
chip and FC1 was used as a background control. The response difference ( $\triangle \mathrm{RU})$ between FC1 and FC2 is shown. PipX $(2 \mu \mathrm{M})$ was injected in absence of effector molecules (solid line), in the presence of $2 \mathrm{mM}$ ADP (long dashed line), $2 \mathrm{mM}$ ATP $+1 \mathrm{mM}$ 2-OG (middle dashed line), $2 \mathrm{mM}$ $\mathrm{ADP}+2 \mathrm{mM} \mathrm{ATP}+1 \mathrm{mM}$ 2-OG (short dashed line) and $4 \mathrm{mM}$ ADP $+2 \mathrm{mM}$ ATP $+1 \mathrm{mM}$ 2-OG (dotted line)

\section{Figure S1 SPR detection of $\mathrm{P}_{\mathrm{II}}$-PipX complexes using $\mathrm{Ni}^{2+}$-loaded NTA chip}

His $_{6}$-PipX (500 nM) was preincubated with homotrimeric Strep- $\mathrm{P}_{\mathrm{II}}(100 \mathrm{nM})$ in the absence (dotted line) and in the presence of $1 \mathrm{mM}$ ADP (dashed line) and injected on the $\mathrm{Ni}^{2+}$-loaded NTA chip. Solid line corresponds to the control binding experiment of His 6 -PipX in the absence of $\mathrm{P}_{\mathrm{II}}$. The sensorgram shows the increase of RU (resonance units) that represents the protein binding to the chip surface. The difference in the RU between binding experiments in the presence of $P_{I I}$ and the control (PipX alone) at $\mathrm{t}=197 \mathrm{~s}$, indicated by an arrow, was used to quantify the amount of PipX-P $\mathrm{P}_{\mathrm{II}}$ complex formation.

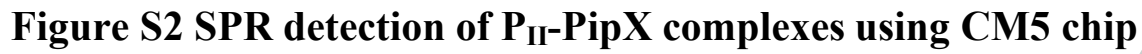

Homotrimeric Step- $\mathrm{P}_{\text {II }}(3.2 \mu \mathrm{M})$ was immobilized to FC2 of the Strep-Tactin-coated CM5 chip and FC1 was used as a background control. His 6 -PipX $(2 \mu \mathrm{M})$ was injected in absence of effector molecules (solid line), in the presence of $1 \mathrm{mM}$ ATP (dotted line) and of $1 \mathrm{mM} \mathrm{ATP}+1 \mathrm{mM} 2-\mathrm{OG}$ (dashed line). 


\section{Tables and Figures}

\section{Table 12 2-OG binding to $P_{I I}$ in the presence of various ADP/ATP ratios}

Values correspond to the mean of three experiments \pm SEM. The raw data were fitted using one-site and three-sites binding models for a $\mathrm{P}_{\mathrm{II}}$ trimer. For comparison, the 2-OG binding in the presence of $1 \mathrm{mM}$ ATP data fitted according to the three sites binding model are given in parentheses. NF, non fittable.

\begin{tabular}{cccccc}
\hline & \multicolumn{2}{c}{ one-site binding model } & \multicolumn{3}{c}{ three-sites binding model } \\
ADP:ATP & $\mathrm{N}$, sites & $\mathrm{K}_{\mathrm{d}}, \mu \mathrm{M}$ & $\mathrm{K}_{\mathrm{d}} 1, \mu \mathrm{M}$ & $\mathrm{K}_{\mathrm{d}} 2, \mu \mathrm{M}$ & $\mathrm{K}_{\mathrm{d}} 3, \mu \mathrm{M}$ \\
\hline $0: 1$ & $1.725 \pm 0.01$ & $38.9 \pm 1.1$ & $(5.1 \pm 4.0)$ & $(11.1 \pm 1.8)$ & $(106.7 \pm 14.8)$ \\
$0.25: 1$ & $1.35 \pm 0.16$ & $78.2 \pm 18$ & $12.2 \pm 6.4$ & $41.2 \pm 28.8$ & $263.5 \pm 153.1$ \\
$0.5: 1$ & $1.125 \pm 0.15$ & $95.0 \pm 16.5$ & $11.0 \pm 6.0$ & $19.8 \pm 2.1$ & $194.9 \pm 45.0$ \\
$1: 1$ & $0.75 \pm 0.26$ & $182.9 \pm 4.3$ & & $\mathrm{NF}$ & \\
\hline
\end{tabular}


Figure 1

A

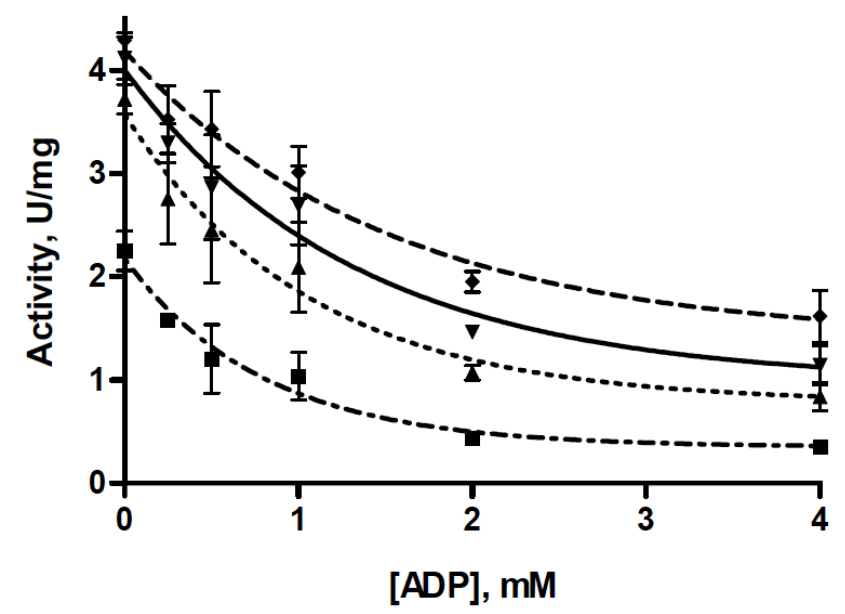

B

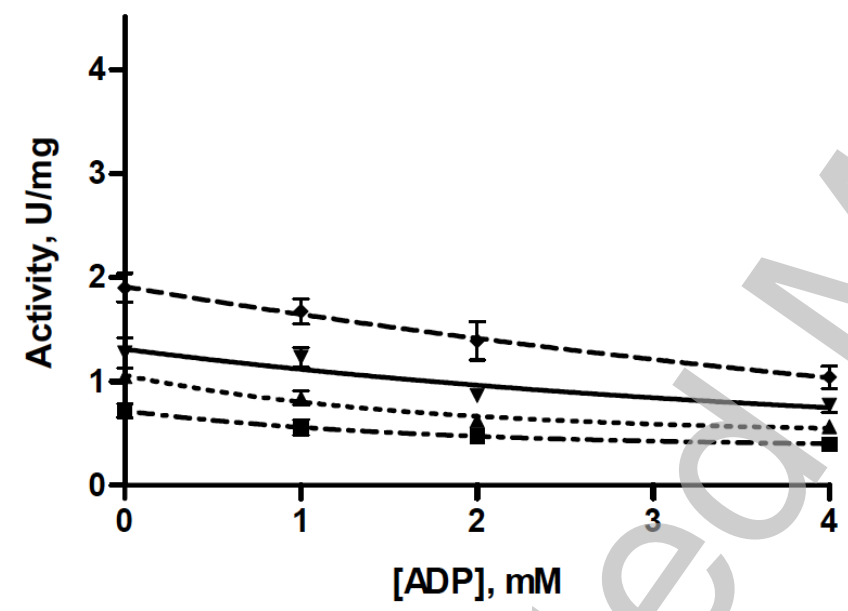

Licenced copy. Copying is not permitted, except with prior permission and as allowed by law.

(C) 2011 The Authors Journal compilation (c) 2011 Portland Press Limited 
Figure 2

A

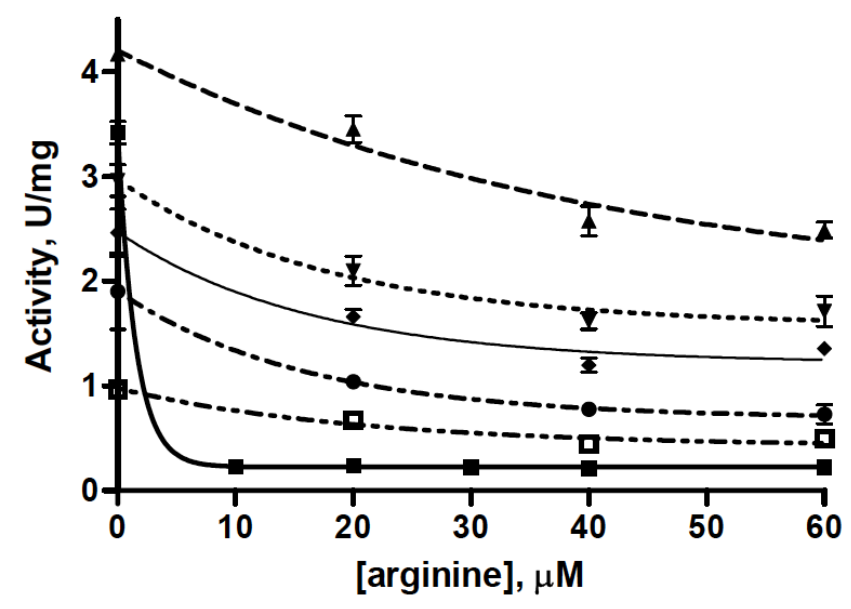

B

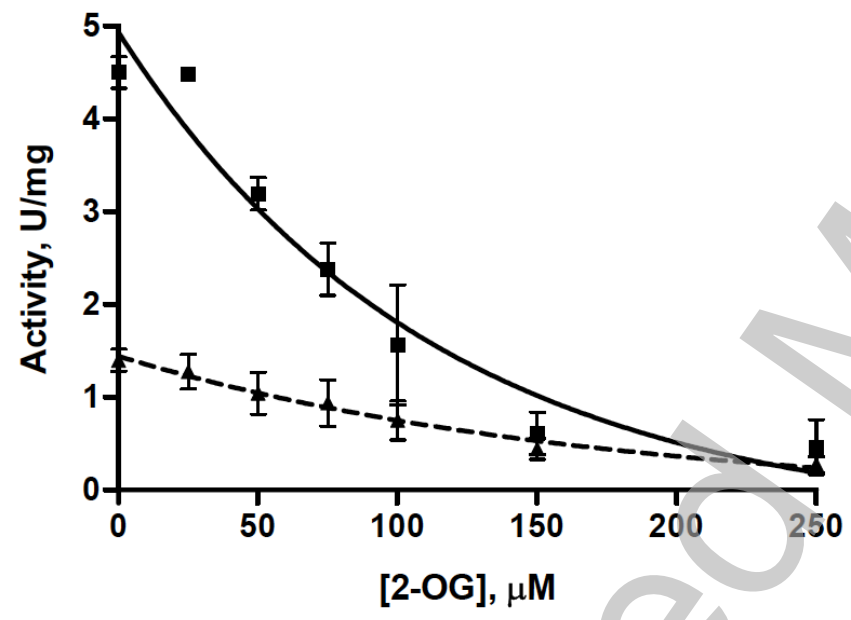

Licenced copy. Copying is not permitted, except with prior permission and as allowed by law.

(C) 2011 The Authors Journal compilation (c) 2011 Portland Press Limited 
Figure 3

A

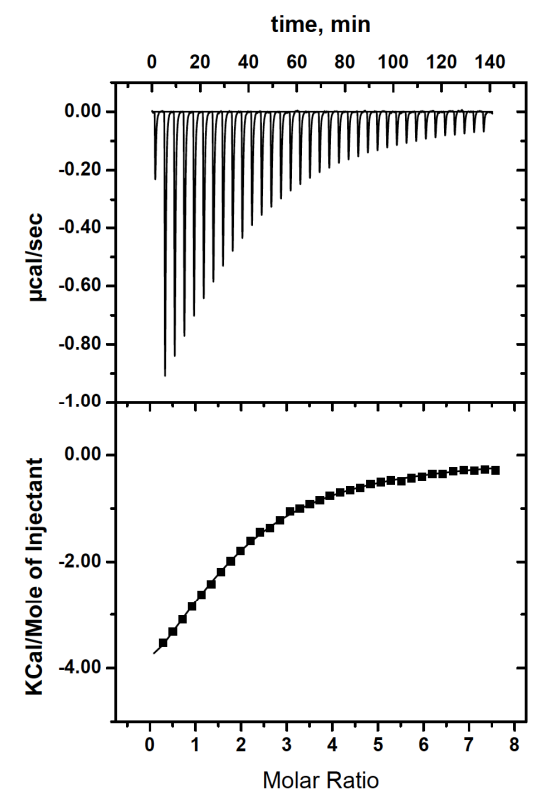

C

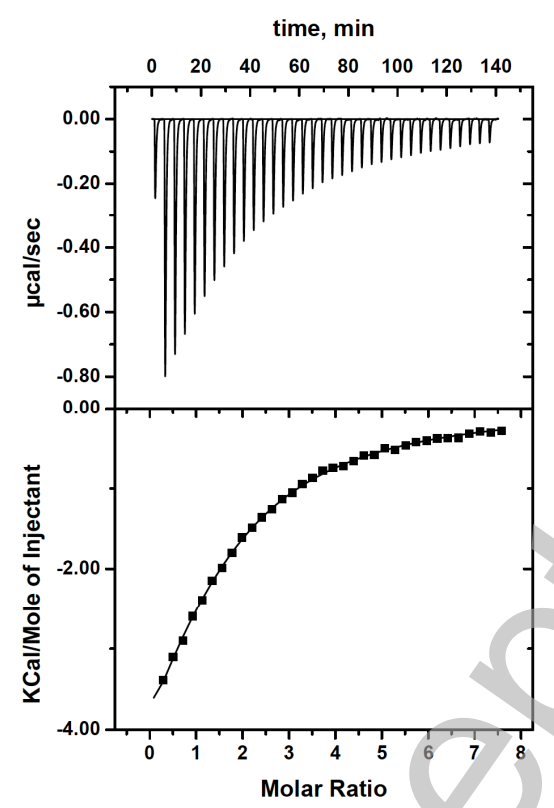

B

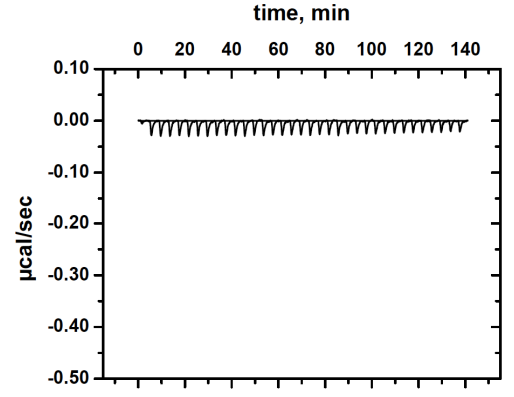

$\mathrm{D}$

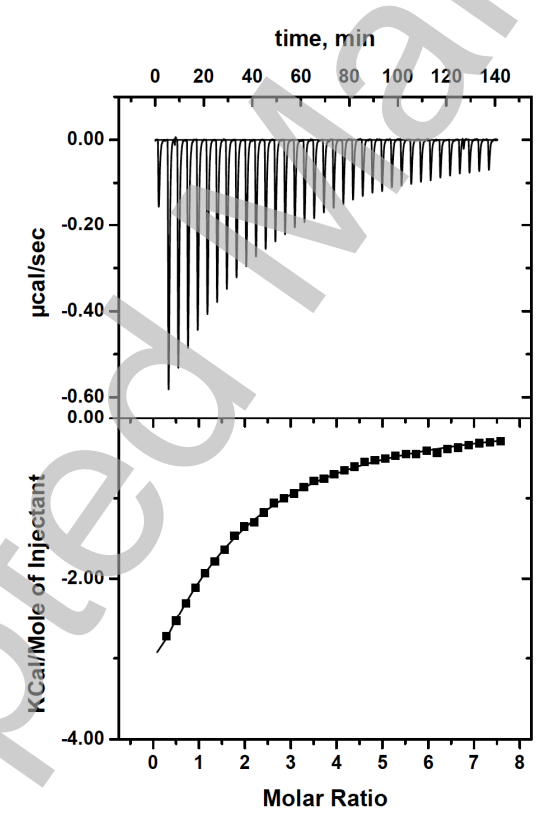

E

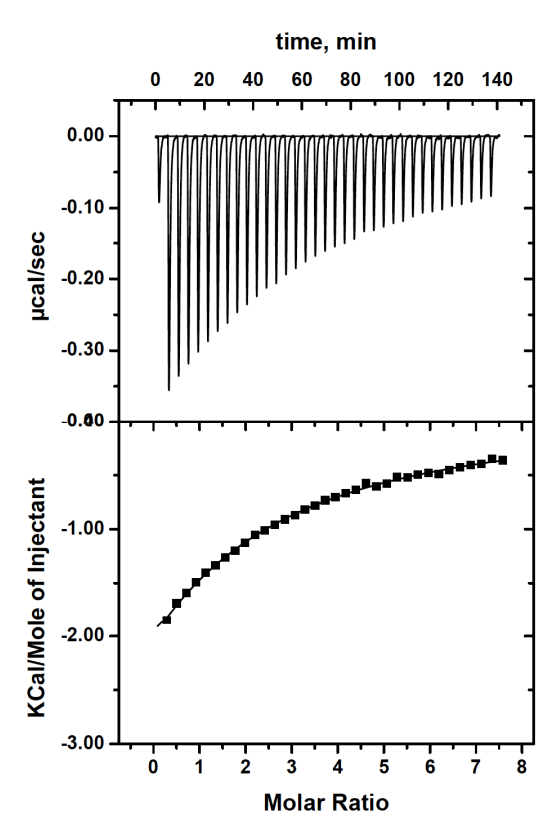

Licenced copy. Copying is not permitted, except with prior permission and as allowed by law. 
Figure 4

A

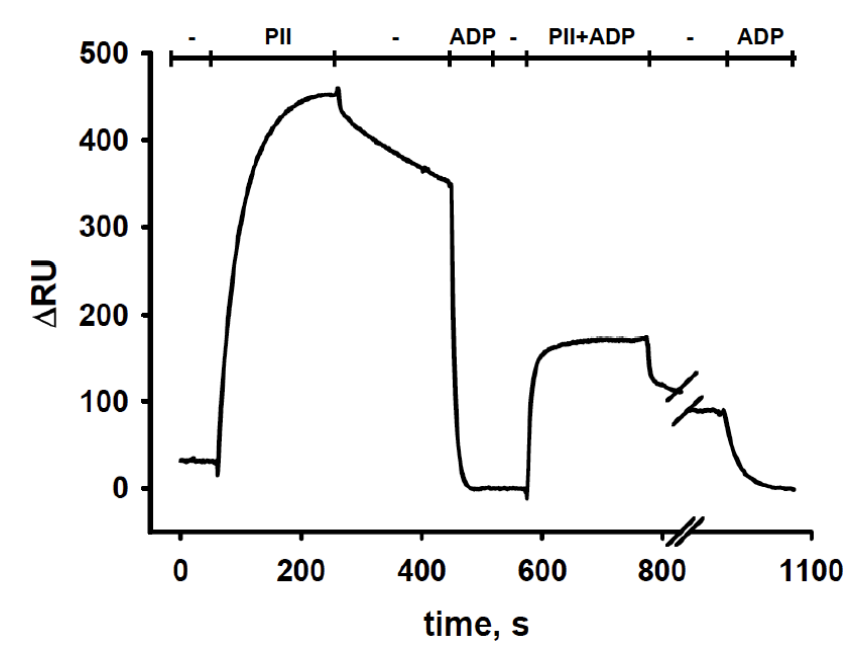

B

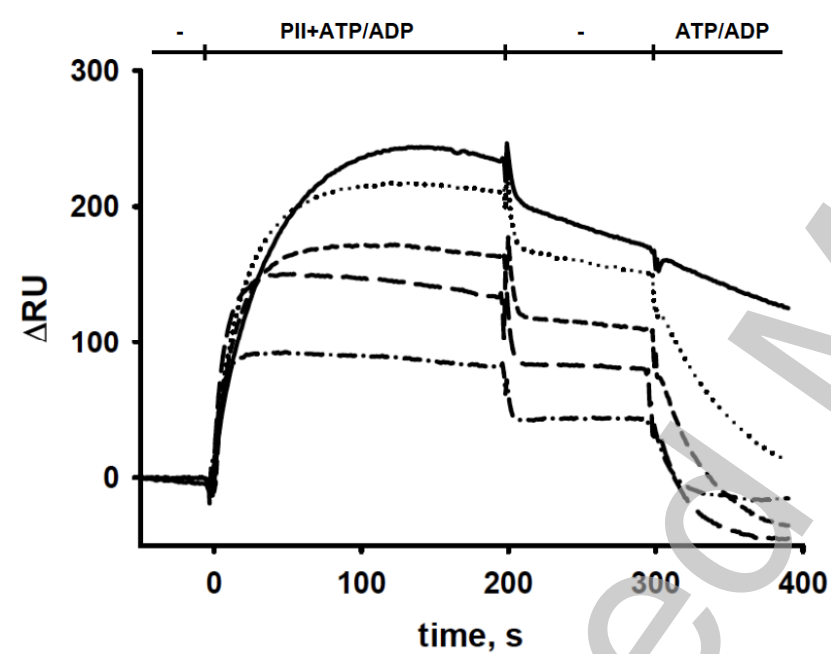

Licenced copy. Copying is not permitted, except with prior permission and as allowed by law.

(C) 2011 The Authors Journal compilation (c) 2011 Portland Press Limited 
Figure 5

A

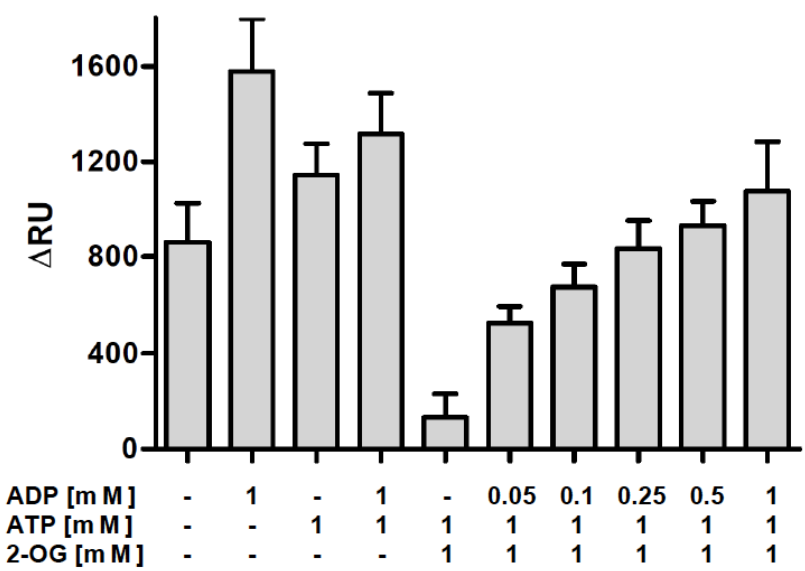

B

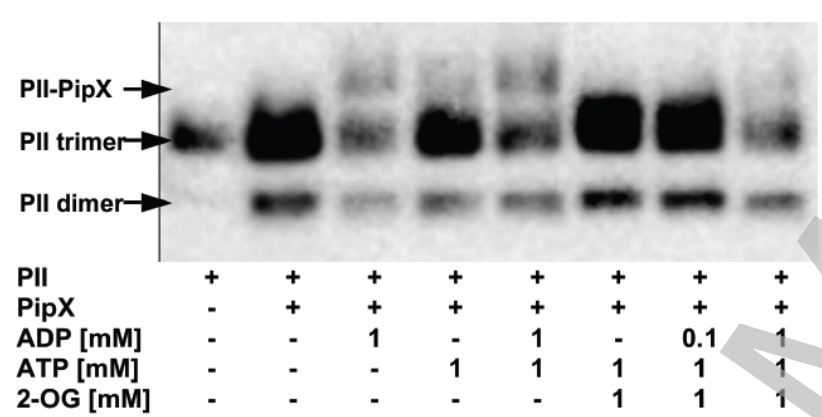

$\mathrm{C}$

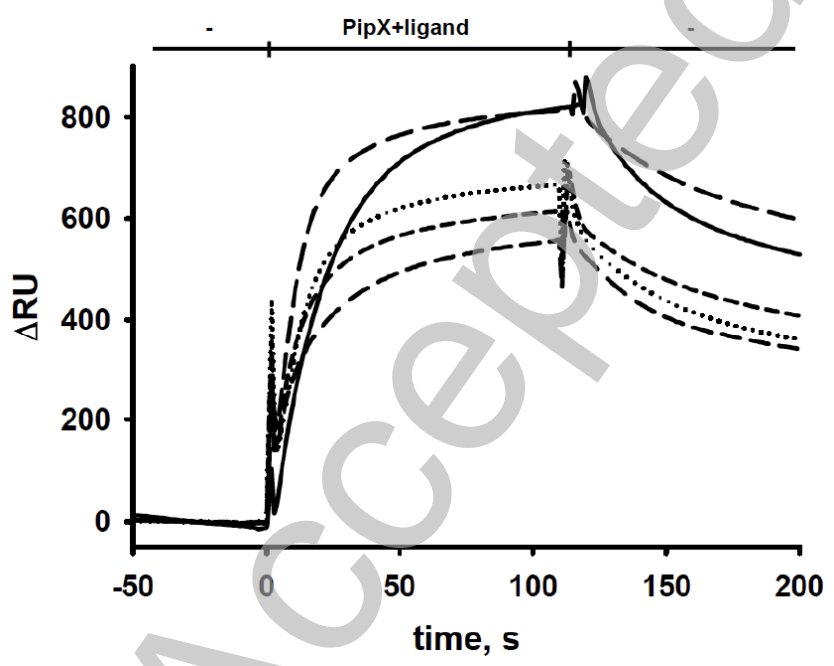

